\title{
Yeşilova Yerel Halkının İlçe Turizmine Bakış Açılarının Belirlenmesi
}

\author{
Öğr. Gör. Ali ELIBBOL \\ Burdur Mehmet Akif Ersoy Üniversitesi Yeşilova İsmail Akın Yüksekokulu \\ aelibol@mehmetakif.edu.tr \\ https://orcid.org/0000-0002-0414-1009 \\ DOI: https://doi.org/10.37847/tdtad.788132 \\ Makale Türü: Araştırma Makalesi \\ Makale Gönderim Tarihi: 31.08 .2020 \\ Makale Kabul Tarihi: 24.11.2020
}

\section{Özet}

Bu çalışmanın amacı, Yeşilova ilçesi turizm potansiyelinin ve Yeşilova halkının turizme yönelik bakış açılarının belirlenmesidir. Ayrıca araştırmada yerel halkın ilçesinin turizm potansiyeli hakkında ne ölçüde bilgiye sahip olduğunu ve ilçenin turizm potansiyelini daha da arttırabilmek için Yeşilova'da hangi turizm türlerine ağırlık verilmesi gerektiğini ortaya çıkarabilmektir. Bu amaç kapsamında araştırmada kolayda örnekleme yöntemi kullanılarak veriler yerel halk ile yüz yüze yapılan anket ile toplanmıştır. Araştırmada kullanılan anket formu 25 önermeden oluşturulmuştur. Daha sonra 22 önermenin boyutlarını oluşturabilmek için faktör analizi yapılmıştır. Yapılan faktör analizi sonucunda 22 önerme dört boyuta indirgenmiştir. Diğer 3 önerme ise faktör analizi dişında bırakılarak bu önermeler yerel halkın Yeşilova'nın doğal ve kültürel zenginliklerini bilme düzeyini, Yeşilova'da turizm denince yerel halkın akıllarına ilk neresinin geldiğini ve Yeşilova'da ağırlık verilmesi gereken turizm türünün ne olduğunu ölçmek için oluşturulmuştur. Araştırmaya katılan katılımcılar üzerinde yapılan 186 anket uygulamasından elde edilen veriler neticesinde ortaya çıkan sonuçlar ise, Salda Gölü'nün, Beyaz Adalar'ın ve Salda Kayak Merkezi'nin ilçe tanıtımında ve pazarlanmasında mutlaka kullanılması gerektiği sonucuna ulaşılmıştır. Ayrıca araştırmada Yeşilova'nın zengin bir potansiyele sahip olduğunun fakat bu zengin potansiyelin yeterince kullanılmadığının, ilçe turizminin geliştirilmesi için turizm yatırımlarının arttırılması gerektiğinin, ilçenin wc, lavabo, duş, konaklama, yeme ve içme gibi çeşitli altyapı sorunlarının olduğunun, bu sorunların ortadan kaldırılması için yerel paydaşlar arasında etkin bir iletişim ve koordinasyonun olmadığının sonuçlarına da ulaşılmıştır. Bu bağlamda hem yöre halkı hem yerel paydaşlar hem de turizm işletmeleri, bu çalışmayı incelediği zaman Yeşilova ilçesinde ivedi bir şekilde nelerin yapılması gerektiğgi konusunda bilgi sahibi olacaklardır.

Anahtar Kelimeler: Yeşilova, Yeşilova Turizm Potansiyeli, Salda Gölü ve Salda Kayak Merkezi.

\section{Determination of Perspectives of Yeşilova Local People on District Tourism}

\begin{abstract}
The aim of this study is to determine the tourism potential of Yeşilova district and the outlooks of the people of Yeşilova towards tourism. In addition, the study aims to reveal to what extent the local people have knowledge about the tourism potential of the district and which types of tourism should be focused on in Yeşilova in order to further increase the tourism potential of the district. Within the scope of this purpose, the data were collected by face-to-face survey method with the public by using the convenience sampling method. The questionnaire form used in the research was composed of 25 questions. Subsequently, factor analysis was conducted to establish the dimensions of 22 questions. As a result of the factor analysis, 22 statements were reduced to four dimensions. 3 questions which were established to measure the level of knowledge of the local people regarding
\end{abstract}


the natural and cultural richness of Yeşilova, what is the first thing that comes to the mind of the local people when tourism is mentioned in Yeşilova and what type of tourism should be focused on in Yeşilova were excluded from the factor analysis. As a results of the data obtained from the 186 questionnaires conducted on the participants of the study, it was concluded that Lake Salda, Beyaz Adalar (White Islands) and Salda Ski Resort should be used in the promotion and marketing of the district. In addition, in the study it was determined that Yeşilova has a rich potential but this rich potential is not used sufficiently, that tourism investments need to be increased for the development of district tourism, that the district has various infrastructural problems such as inadequate WC, washbasin, shower, accommodation, food and beverage facilities and there was no effective communication and coordination among the local stakeholders to eliminate these problems. In this context, both local people, local stakeholders and tourism enterprises will have information about what needs to be done urgently in Yeşilova district when they examine this study.

Keywords: Yeşilova, Yeşilova Tourism Potential, Salda Lake and Salda Ski Center.

\section{GİRİ̧}

Turizm, seyahat edenlerden veya seyahat edenlerin gereksinimlerini karşılayan hizmet sektörlerinden gelen heyecan verici talepler doğrultusunda faaliyet alanlarını genişletmiştir. $\mathrm{Bu}$ sayede çok boyutlu bir faaliyet alanına sahip olan turizm, hem yerli hem de yabancı turistlerin dikkatlerini çekerek onların yaşam tarzlarını etkilemiştir (Cook \& Hsu \& Marqua Çevirmen: Tuna, 2016: 5,). Bundan dolay1 turizm, yerli ve yabanc1 turistlere hizmet sunma, yerli ve yabanc1 turistlerin yeme-içime, eğlenme, dinlenme, diğer ihtiyaçlarını karşılama ve farklı kültürleri bir araya getirme perspektifinden sosyo-kültürel, yabanc1 turistlerin ülkeye döviz getirme ve istihdam oluşturma perspektifinden ekonomik ve oluşturmuş olduğu kaynak kullanım talepleri perspektifinden de çevresel bir faaliyettir (Doğan \& Üngüren, 2012: 104).

Yirminci yüzyılın ortalarında ortaya çıkan ekonomik, sosyo-kültürel, çevresel ve psikolojik değişimler, bireylerin turizm alışkanlıkları ve ihtiyaçları üzerinde önemli derecede etkiler yaratmıştır. (Usta, 2016: 1). Özelliklede ülkemizde turizm hareketleri yaz aylarında deniz, kum ve güneş üçlüsü üçgeninde gelişerek önemli bir kitle turizm faaliyeti olarak karşımıza çıkmaktadır. Fakat kıyılarda yoğunlaşan bu turizm faaliyetleri farklı problemleri ortaya çıkarmış ve bunun neticesinde de bireylerin turizm anlayışlarını günümüzde alışılmış turizm merkezlerinden uzak, doğa ile iç içe ve çevre ile uyumlu bir şekilde entegre olmuş tesislerde yapılan faaliyetler olarak değiştirmiştir (Ceylan \& Demirkaya, 2009: 82; Yılmaz \& Şahin, 2009: 350).

Dünya Turizm Örgütü 'de 2011 yılında yayınladığı raporda günümüzdeki turist tercihlerinin sadece deniz, kum ve güneş üçgenine bağlı olmadığını belirterek artık günümüzde farklı turizm faaliyetlerinin önem kazandığını ve özelliklede kırsal turizm alanlarına doğru bir kayma olduğuna dikkat çekmiştir (Orhan \& Karahan, 2010: 27-28). Günümüzde turizmle ilgili kamu ve özel yönetimler ile girişimcilerde, deniz-kum-güneş üçgenine bağlı turizminin kültürel miras, doğa, tarih, sağlik ve aktivite turizmi türleri ile desteklenmesi gerektiğini vurgulamışlardır (Duman, Kozak ve Uysal, 2007: 212). Bu nedenle Burdur'un Yeşilova ilçesinde yer alan Türkiye'nin en temiz gölü olan Salda Gölü'de günümüzde her geçen gün daha çok kişinin ziyaret ettiği ve yerli ile yabancı turistlerin alternatif turizm faaliyetlerini gerçekleştirebilecekleri bir yapıya sahiptir. Bu özellik sayesinde Göller Bölgesi Eko-turizm Gelişim Bölgesi kapsamına alınan Salda Gölü’de, kırsal turizm açısından büyük bir öneme sahiptir (Temurçin \& Tozkoparan, 2020: 99). Ayrıca Yeşilova İlçesi Türkiye'nin en temiz gölü olan Salda Gölü'nü bünyesinde bulundurmasının yanında ilçe, çeşitli doğal ve kültürel turizm kaynaklarını da bünyesinde bulundurmaktadır. 
Alternatif turizm türlerinin ve ürün çeşitlendirme faaliyetlerinin önem kazandığ 1 günümüzde, Yeşilova'nın sahip olduğu doğal, tarihi ve kültürel varlıkların, sürdürülebilir turizm çerçevesinde değerlendirilerek birer turizm ürünü olarak en iyi şekilde tasarlanması, tanıtılması, pazarlanması, kaliteli hizmetlerin sunulması, kalifiyeli eleman, alt ve üst yapı gibi hizmet faaliyetlerini geleceğe yönelik etkin ve verimli bir şekilde planlanması büyük bir önem arz etmektedir.

Bu kapsam doğrultusunda; yukarıda bahsedilen konulardan hareketle, bu çalışmada öncelikle Yeşilova ilçesindeki turizm potansiyeli, turizm arz kaynakları, turizm potansiyelinin Yeşilova ilçesinin gelişmesine etkisi ele alınmış ve daha sonra ampirik bir uygulama ile yerel halkın Yeşilova turizmine bakışları, Yeşilova turizminin öncelikli görülen sorunları ve turizm faaliyetlerinin Yeşilova'nın gelişimine olan katkıları incelenmiştir. Bu amaç doğrultusunda araştırma iki kapsamda ele alınmıştır. Araştırmanın birinci bölümünde Yeşilova ilçesinin coğrafi konumu ve turizm arz kaynaklarına değinilmiştir. İkinci bölümde ise yerel halkın Yeşilova turizm potansiyeline bakış açılarını inceleyebilmek için anketle toplanan veriler analiz edilmiştir. Daha sonra elde edilen sonuçlar yorumlanarak yerel halkın bakış açılarına göre Yeşilova turizminin alt yapı sorunlarının ortadan kaldırılabilmesi ve Yeşilova turizm potansiyelinin sürdürülebilmesi için önerilerde bulunulmuştur. Ayrıca Yeşilova turizmi ile ilgili literatür incelendiğinde, yerel halkın ilçe turizmine bakış açılarını ele alan bir çalışmaya rastlanmamıştır. Dolayısıyla yapılan bu çalışma Yeşilova İlçe turizmine farklı bir bakış açısı kazandırması açısından önem taşımaktadır.

\section{YEŞILLVA İLÇESİ'NIIN COĞRAFİ KONUMU}

Türkiye'nin en derin ve en temiz Salda Gölü'nü bünyesinde barındıran Yeşilova İlçe' si Akdeniz Bölgesi'nin güneybatısında yer alan Burdur İli'nin en eski yerleşim yeridir (Salda Gölü Raporu, 2020: 5-6). Çünkü Mellart'ın (1954) ve Özsait'in (1982-1983) yürüttüğü kazı çalışmalarında ortaya çıkan buluntulara göre ilçedeki yerleşik hayatın Kalkolitik Döneme kadar uzandığı tespit edilmiştir (Mellart, 1954: 192; Özsaid, 1984: 75-76). Ayrıca Yeşilova İlçesi açısından önem arz eden Sultan Pınarı'nın ismi önemli bir tarihi savaşa şahitlik etmektedir. Bu tarihi savaş, Alman İmparatoru Frederik Barbaros Haçlı ordusunun başında Yeşilova ilçesi yakınlarına kadar gelmiştir. Bu ilerleyişi durdurmak isteyen Konya Sultanı bölgeye Osman Bey ile Hüsamettin Beyi göndermiştir. Osman Bey ve Hüsamettin Bey bölgede Aleksi'yi her iki yönden sıkıștırmıșlar ve Köpekbeli civarında çetin bir muharebe gerçekleşmiştir (Ongun, Gövdere ve Çiçek, 2016: 83). Bu muharebede ağır yaralanan Osman Bey'in manevi evladı Abdi Bey Salda Gölü Eşeler dağının kuzeydoğu sırtlarındaki yörede bulunan bir revirde tedavi altına alınmış ve büyük cesaretinden dolayı komutana Konya Sultanı sultanlık payesi vermiştir. Bu nedenle de yöreye Sultan Payesi ismi verilmiş ve zamanla bu isimde bugünkü kullanılan Sultan Pınarı ismine dönüşmüştür (Yeşilova, 2020).

Yeşilova ilçesi konum olarak, Güneybatı Anadolu'da Göller Bölgesi'nde olup, ilçenin doğusunda Burdur ili, batısında Acıpayam ilçesi, güneyinde Karamanlı ilçesi, kuzeyinde ise Denizli ili bulunmaktadır. $1351 \mathrm{~km}^{2}$ alana ve 1150 metre rakıma sahip olan Yeşilova ilçesi Burdur il merkezine $60 \mathrm{~km}$, Denizli il merkezine $86 \mathrm{~km}$ ve Antalya il merkezine $145 \mathrm{~km}$ mesafe uzaklıktadır (Göller Bölgesi Aylık Hakemli Ekonomi ve Kültür Dergisi Ayrıntı, 2017: 12). 
Şekil 1. Yeşilova İlçesi Coğrafi Konumu

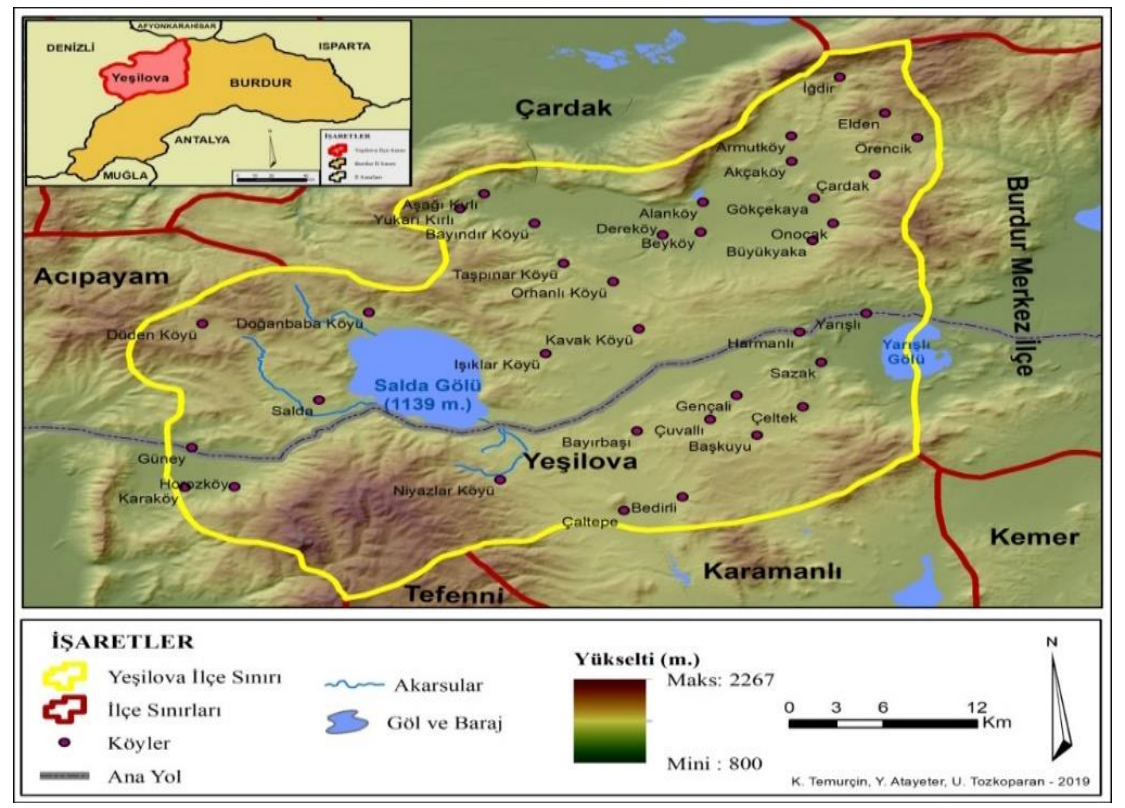

Kaynak: Temurçin \& Atayeter ve Tozkoparan, (2019), s. 42.

\section{YEŞİLOVA İLÇESI’'NİN TURIZM ARZ KAYNAKLARI}

21. yüzyılda teknolojinin gelişmesi ve internetin yaygınlaşması artık bireylere daha yeni ve daha farklı destinasyonlara seyahat etme imkânı sağlamıştır (Lopez-Guzman \& Sanchez-Canizares, 2012: 63). Bu nedenle bireyler artık deniz, kum ve güneș üçgenini oluşturan kitle turizmi yerine daha farklı alternatiflere yönelmișler ve bu yönelișlerde alternatif turizm türlerinin ortaya çıkmasını sağlamıştır (Arslaner \& Erol, 2017: 423). Alternatif turizm; deniz, kum ve güneş üçgenini oluşturan kitle turizminin çevre ve sosyal yapı üzerindeki olumsuz etkilerini azaltmak (Akoğlan ve Bahçe, 2009: 95) amaciyla çeşitli turizm aktiviteleri ile farklı bölgelerde turizmi 12 aya yayan bir turizm türüdür (Çelik, 2018: 194). Alternatif turizm açısından doğal kaynak stoklarının korunması, temiz bir çevrenin meydana getirilmesi ve yerel halkın turizm algısı dikkate alınarak yerel halka ekonomik anlamda bir getiri sağlamak son derece önemlidir ( Taş, Düz, \& Ünlü, 2016: 354).

Yeşilova ilçesi, arkeolojik kalıntılarıyla, höyükleriyle, el sanatlarıyla, kayak merkeziyle, Eşeler Yaylasıyla ve Salda Gölüyle turizm potansiyeli yüksek olan bir konuma sahiptir. Özellikle de günümüzde Salda Gölü, Nasa'nın (2020) Twitter hesabından yapmış olduğu "Türkiye'deki Salda Gölü, Mars'taki Jezero Krateri ile jeolojik benzerliklere sahiptir. Hatta araştırmacılar 2020'deki Mars görevi için Salda Gölü'nde saha araştırması yapmışlardır" paylaşımı, Balcı vd. (2018), Kesici vd. (2018) ve Russell ve diğerlerinin (1999) yapmış oldukları araştırmalarda elde ettikleri bulgular neticesinde günümüzden 3.7 milyar yıl önceye dayanan hidromanyezit stromatolit oluşumu sonucunda meydana gelen Mars toprağı özelliğine sahip beyaz kumsalıyla ilçe turizmi için büyük bir öneme sahiptir (Balc1 vd. 2018: 36; Russell vd. 1999: 885; Kesici vd. 2018: 6). Yeşilova İlçesi'nin önem arz eden diğer turizm kaynakları Tablo 1'de gösterilmiştir. 
Tablo 1. Yeşilova İlçesi’nin Önem Arz Eden Turizm Kaynakları

\begin{tabular}{|c|c|}
\hline $\begin{array}{l}\text { Turizm Arz } \\
\text { Kaynakları }\end{array}$ & $\mathbf{k A}$ \\
\hline $\mathrm{Da}$ & ölünü cevreleve \\
\hline $\mathrm{ai}$ & $\begin{array}{l}\text { Tinaz Tepe bünyesinde bulunan } 860 \text { metre uzunluğunda telesiyej hattı } \\
\text { ve uzunlukları } 1000 \text { ile } 1500 \text { metre arasında değişen } 5 \text { adet piste sahip } \\
\text { Salda Kayak Merkezi }\end{array}$ \\
\hline Göl & $\begin{array}{l}\text { Navlu, Sazak ve Düğer köyleri arasında } 2000 \text { dekarlık bir alanı } \\
\text { kaplayan Yarışlı Gölü ile } 1989 \text { yılında doğal sit alanı olarak koruma } \\
\text { altına alınan (Burdur İl Raporu, 1996: 45) ve } 185 \text { metre derinliğe sahip } \\
\text { Türkiye'nin en derin üçüncü doğal gölü, Türkiye'nin en temiz ve } \\
\text { Mars toprakları özelliğine sahip olan Salda Gölü (Tozkoparan, 2020: } \\
\text { 28). }\end{array}$ \\
\hline $\begin{array}{l}\text { İnanç } \\
\text { Turizmi }\end{array}$ & $\begin{array}{l}\text { Onocak Köyünde bulunan keramet sahibi ve ruhsal bozukluğu olan } \\
\text { hastaları tedavi eden Veli Dede'nin mezarının bulunduğu Veli Dede } \\
\text { Türbesi (İpekçioğlu, 2014: 4) ile Hacı Bektaş- i Veli'nin pirlerinden } \\
\text { bir tanesi olan Niyazi Baba'nın mezarının ve iki lahitin bulunduğu } \\
\text { Niyazi Baba Türbesidir (Kalafat, 1999: } 515 \text { ). }\end{array}$ \\
\hline $\begin{array}{l}\text { Yayla } \\
\text { Turizmi }\end{array}$ & $\begin{array}{l}\text { Akçaköy Yaylası ile ilçeye } 18 \text { km uzaklıkta bulunan Eşeler yaylasıdır. } \\
\text { Yaylanın en yüksek noktası } 2268 \text { metre yükseltiye sahip Eşeler Dağı } \\
\text { olarak bilinen tepedir. En alçak noktası ise, } 895 \text { metre yüksekliğe } \\
\text { sahip Dalaman çayı ile kesiştiği Bedirli Köyü kıyısıdır.(Dağdaş ve } \\
\text { Ünlü, 2002: 2). }\end{array}$ \\
\hline \multicolumn{2}{|r|}{ Tarihsel Değerler } \\
\hline $\begin{array}{l}\text { Höyük ve } \\
\text { Ören Yerleri }\end{array}$ & $\begin{array}{l}5 \text { metre yüksekliğe ve } 135 \text { metre çapa, Kalkolitik, Geç Neolitik ve } \\
\text { Akeramik Neolitik Çağlar'a ait üç kültür evresine sahip olan Hacılar } \\
\text { Büyük Höyük (Değirmencioğlu ve Ahipaşaoğlu, 2008: 91), Roma } \\
\text { Devrine ve Eski Tunç Çağ'ına ait keramik parçalarına rastlanılan } \\
\text { Dereköy Aşağı Höyüğü, öğütme taşları, tuğlalaşmış kerpiç parçalarına } \\
\text { ve çakmak taşlarına rastlanılan Dereköy Yukarı Höyüğü, Yarışlı } \\
\text { Höyüğü, Gebrem Höyüğü, Mancarlı Höyüğü, Gençali Höyüğü, } \\
\text { Bizans-Roma devirlerine ait buluntulara rastlanan Takina Ören yeri, } \\
\text { Çaltepe Ören yeri ile Yazır Höyüğüdür (Burdur İl Külttür ve Turizm } \\
\text { Müdürlüğü, Kültür Envanteri, Burdur İlçeleri, 2007: 220-229). }\end{array}$ \\
\hline
\end{tabular}


Şekil 2. Yeşilova İlçesi Turizm Arz Kaynakları

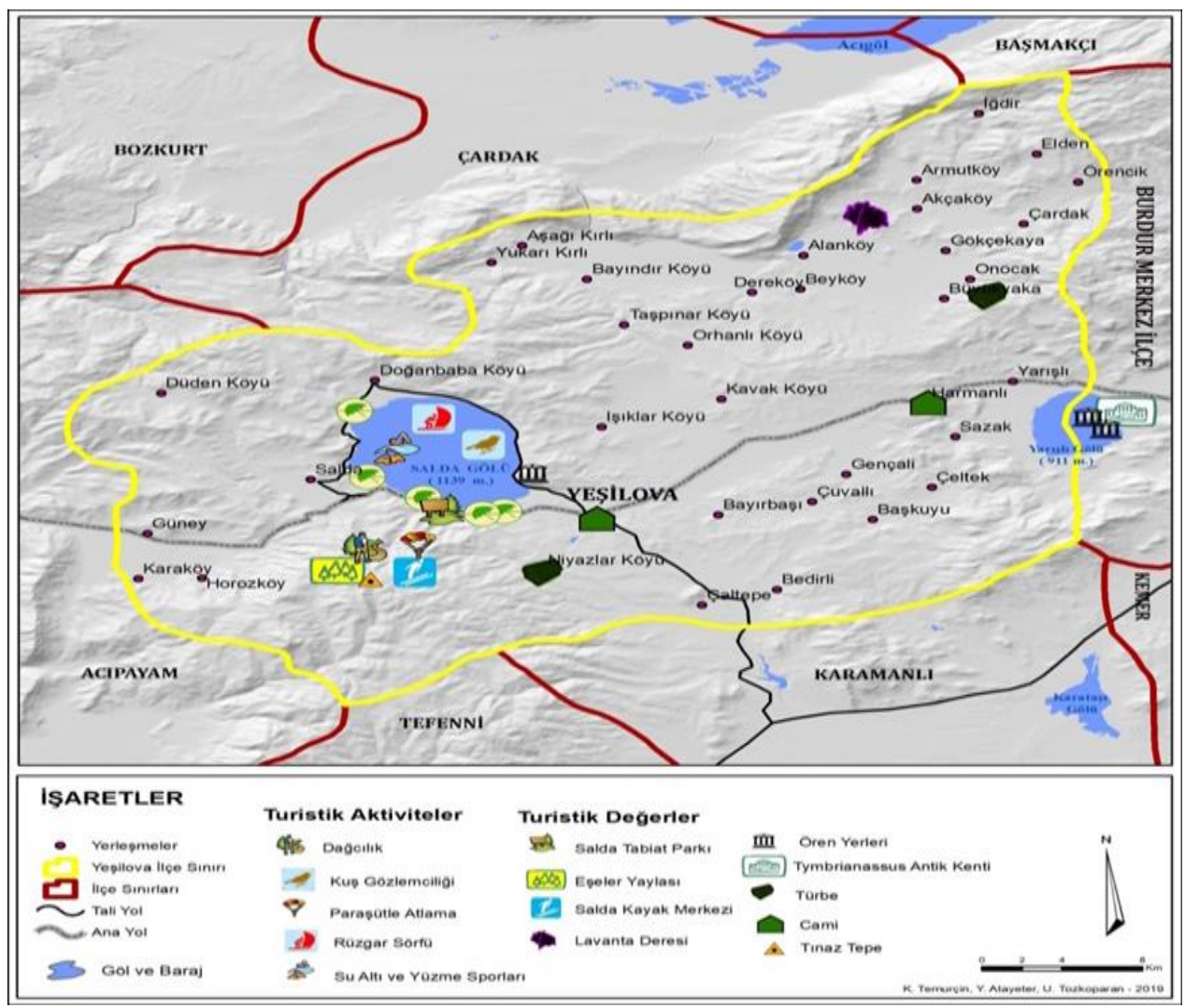

Kaynak: Temurçin \& Atayeter ve Tozkoparan, (2019), s. 44.

Herhangi bir bölgenin yerli veya yabancı turistleri cezbedebilmesi ve turistlerin o bölgeyi ziyaret etme dürtüsünü ortaya çıkarıp turistleri harekete geçirebilmesi için üç önemli temel unsur bulunmaktadır. Bu unsurlar turizmin temel unsurları olan bölgenin çekiciliği, bölgeye erişebelirlilik ve bölgede yerli veya yabancı turistlerin geceleme ihtiyacını karşılayacak olan konaklamadır (Ceylan, 2004: 63). İlçe; Salda Gölü, Yarışlı Gölü ve Salda Kayak Merkezi gibi değerlere sahip olmasından dolayı turistik çekicilik açısından önemli bir potansiyele sahiptir. Fakat ilçe sahip olduğu bu değeri tam kapasiteli bir şekilde kullanamamaktadır. İkinci unsur erişim kapsamında Yeşilova, turizmin merkezi sayılan Antalya'ya, ayrıca Burdur, Isparta ve Denizli'ye komşu olması ilçeye büyük bir avantaj sağlamaktadır. Bu dört ilin turizm potansiyeli dikkate alınarak oluşturulacak bir tur güzergâhına ilçesinin de eklenmesi Yeşilova turizm potansiyeline katkı sağlayacaktır. İnanır ve Ongun'un (2019) ile Temurçin ve Tozkoparan'nın (2020) yapmış oldukları araştırmalarda ulaştıkları sonuçlara göre üçüncü ve son unsur olan konaklama konusunda ise ilçenin gidermesi gereken büyük eksiklikleri ve yapması gereken büyük yatırımlara ihtiyacı vardır. Ayrıca Temurçin ve Tozkoparan'nın (2020) yapmış oldukları araştırmada ulaştıkları sonuca göre ilçedeki bu mevcut potansiyel çeşitli nedenlerle yeterince değerlendirilmemesi yerli ve yabancı turistler açısından ilçe sadece uğranılan, ihtiyaç giderilen, günü birlik ziyaret edilen, gezilen, piknik yapılan, konaklama yapılmayan ve turistik turlarda sadece mola verme yeri özelliği olan bir yer olarak görülmüştür. Eğer bu problemeler ortadan kaldırılabilirse, Yeşilova ilçesinin sahip olduğu bu doğal, kültürel ve tarihi değerleri sürdürülebilir turizm kapsamında değerlendirmek, birer turistik 
ürün olarak tasarlamak, tanıtmak ve pazarlamak ilçenin turizm potansiyelin arttırılabilmesi için büyük bir önem arz edecektir.

Yeşilova İlçesi'nin özellikle de Salda Gölü'nün, son yıllarda TRT Haber, CNN Türk ve Haber 7 gibi haber bültenlerinde tanıtımının artması, Derya ULUĞ'un 'Sürgün Aşkımız', Gülden MUTLU'nun 'Çiçek Gibi', İshak TOLGAY ve Yunus Emre TOLGAY'n 'Yallah', Belgin TUNÇBILLEK' in 'Artık Çok Geç' şarkılarının kliplerini Salda Gölü ve Beyaz Adalar' da çekmeleri, Kenan SOFUOĞLU'nun Salda Gölü'nde fliteboard yaparak sosyal medya hesabında paylaşması, ünlü modelist, sunucu ve oyuncu olan Berna ANT'ın bir film ajansının tanıtım çekimlerini Salda Gölü'nde yapması ve rekor dalışlarında milli sporcu Derya CAN ile Şahika ERCÜMEN'in Salda Gölü' nü tercih etmeleri ve bunlara ek olarak yaz ve kış aylarında tur şirketlerinin tur güzergâhlarını Antalya-Denizli-Pamukkale-Yeşilova Salda Gölü-Burdur ve Isparta olarak belirlemeleri gibi nedenlerin etkisi ile Salda Gölü’ne gelen ziyaretçi sayısı çok fazla artmıştır. 2018 ve 2019 yıllarında Yeşilova ilçesine gelen ziyaretçi sayıları aşağıdaki Tablo 2'de verilmiştir. Fakat bu rakamlar kayıt altına alınabilen sayılar olup kayıt altına alınamayanlarla tahmini sayı ise 2 milyonun üzerinde olduğudur.

Tablo 2. Salda Gölü Ziyaretçi İstatistikleri

\begin{tabular}{|l|r|}
\hline \multicolumn{1}{|c|}{ Yıl } & \multicolumn{2}{|c|}{ Ziyaretçi Sayısı } \\
\hline 2018 & 689.730 \\
\hline 2019 & 1.795 .032 \\
\hline 2018 -2019 Değişim Oranı & \% 160.25 Artış \\
\hline
\end{tabular}

Kaynak: Burdur İl Turizm ve Kültür Müdürlüğü verilerinden üretilmiştir.

Yukarıda verilen Tablo 2'deki veriler doğrultusunda Yeşilova ilçesine gelen ziyaretçilerin sayıları incelendiğinde ilçede faaliyet gösteren otel, apart, pansiyon ve yan hizmet tesislerinin ziyaretçilerin ihtiyacını karşılamada yetersiz olduğu görülmektedir. Çünkü ilçede bakanlık belgesine sahip olan 1 otel, belediye belgesine sahip olan 4 otel, 20 apart ve 2 pansiyon bulunmaktadır. İlçede faaliyet gösteren otel, apart ve pansiyonların toplam yatak sayısı ise 607'dir. Bu nedenle ilçeye nicelik ve nitelik bakımından yerli ve yabancı ziyaretçilerin gereksinimlerini karşılayabilecek konaklama ve yan hizmet tesisleri için yatırım yapılması ilçesinin hem turizm potansiyelinin artması hem de sürdürülebilir turizm açısından Yeşilova'nın turizm geleceği için önem arz ettiği düşünülmektedir. Özetle hem Salda Kayak merkezini hem de Türkiye'nin en temiz ve en derin özelliğe sahip Salda Gölü'nü bünyesinde barındıran Yeşilova İlçesi, turizmde alınabilecek bir takım önlemlerle ve araştırma geliştirme politikaları ile büyük bir gelişme, büyüme ve kalkınma sürecini yakalayabilecektir.

\section{YÖNTEM}

\section{Araştırmanın Amacı}

$\mathrm{Bu}$ araştırmanın temel amacını, Yeşilova'daki yerel halkın turizme yönelik tutumlarının belirlenmesi oluşturmaktadır. Bu amaç kapsamında öncelikle Yeşilova'da yaşayan halkın, ilçedeki turizm potansiyeli hakkında ne derece bilgiye sahip olduğu, Yeşilova'da turizm denince yerel halkın aklına ilk neyin veya neresinin geldiği, yerel halkın turizme yönelik görüşlerini ve Yeşilova turizmine ilişkin sorunların olup olmadığının ortaya çıkarılmasıdır. Araştırmada elde edilen sonuçlar ise, Yeşilova turizminin altyapı sorunlarını ortadan kaldırılarak Yeşilova turizm potansiyelinin arttırılabilmesi ve sürdürülebilmesi açısından nasıl stratejiler veya politikalar belirlenmesi gerektiği konusunda yardımcı olacaktır. 


\section{Araştırmanın Kapsamı ve Kısıtları}

Yeşilova yöre halkının turizm olgusuna yönelik tutumlarını belirlemeye yönelik yapılan bu çalışmanın ana kütlesi Yeşilova ilçesinde yaşayan yerel halk oluşturmaktadır. 2019 Aralık ayında Çin'in Wuhan kentinde ilk kez ortaya çıkan covid-19 virüsünün Türkiye'de de görülmeye başlaması ve salgınla mücadele kapsamında devlet tarafından alınan önlem ve kısıtlamalardan dolayı Yeşilova ilçesi genelinde bir araştırma yapılamamış olup örnekleme Yeşilova ilçe merkezinde 186 kişi olarak kolayda örnekleme yöntemi seçilmiştir.

\section{Araştırmanın Yöntemi}

$\mathrm{Bu}$ araştırmada verileri toplamak için anket formu kullanılmış ve kolayda örnekleme yöntemi ile Yeşilova ilçesinde yaşayan 186 katılımcıya anket çalışması uygulanmıştır. Araştırmada Doğan ve Üngüren'in (2012) Isparta yöre halkının Isparta turizmine yönelik görüşlerini incelemek amacıyla geliştirmiş oldukları ölçekten yararlanılmıştır. Doğan ve Üngüren'in 17 önermesine bu araştırmada 5 önerme daha eklenerek önerme sayısı 22'ye çıkarılmıştır. Araştırma kapsamında kullanılan anket formu iki bölümden oluşmaktadır. Anketin birinci bölümünde katılımcılara ait demografik sorulara yer verilirken ikinci bölümün ise, yöre halkının ilçe turizm potansiyeli kullanımı ve geliştirilmesine yönelik görüşlerini belirleyen 22 önermeden oluşmaktadır. Anket formunda yer alan önermeler kapalı uçlu çoktan seçmeli sorulardan oluşmaktadır. Çoktan seçmeli sorular 5'li Likert Tipi Ölçek (Kesinlikle Katılmıyorum, Katılmıyorum, Kararsızım, Katılıyorum ve Kesinlikle Katıliyorum) ölçeği biçiminde düzenlenmiştir. Anketin ikinci bölümü önermeler gereği boyutlara ayrılmıştır. Bu boyutlarda yer alan 6 önerme Yeşilova'nın turizm sorunları, 5 önerme turizmin Yeşilova'ya sağlayacağ katkıları, 4 önerme Yeşilova turizmini geliştirme stratejileri ve 7 önerme Yeşilova'nın turizm potansiyeli kullanımı ve etkinlikler boyutlarını ölçmektedir. Yöre halkının bu boyutlarda yer alan önermelere katılma düzeyleri ise çoktan seçmeli 5'li Likert Tipi Ölçek ile ölçülmeye çalışılmıştır. Toplamda Yeşilova ilçe merkezinde yaşayan 186 katılımcı üzerinde anket çalışması uygulanmıştır.

Araştırma sonucunda elde edilen veriler sosyal bilimlerde kullanılan ve geliştirilen analiz yöntemleri ile analiz edilerek değerlendirilmiştir. 22 önermeden oluşan ölçeğin güvenilirliğini belirlemek için Cronbach Alpha değeri 0,872 olarak hesaplanmıştır. Demografik değişkenlere ilişkin verilerin yorumlanmasında yüzde ve frekans analizleri, yöre halkın turizm olgusuna yönelik tutumlarının hangi boyutlardan oluştuğunu belirlemek amacıyla ölçekteki 22 önermeye faktör analizi uygulanmıştır. Ayrıca araştırmada yöre halkının görüşleri arasındaki farklılıkların değerlendirilebilmesi içinse Anova Analizi kullanılmıştır.

\section{Araștırma Evreni ve Örneklemi}

Araştırmanın ana kütlesini Yeşilova ilçesinde yaşayan yerel halk oluşturmaktadır. Bu nedenle ilçe merkezinde yer alan Merkez Mahallesi ile Koyunlar Çeşme Mahallesi'nde yaşayan toplam 186 katılımcıya anket uygulanmıştır. Çalışmada bu mahallelerin seçilmesinin nedeni ise ilçenin en büyük mahalleri ve pandemi döneminde katılımcılara en kolay ulaşılabilecek noktaların bu mahallelerde olmasidır.

Örneklem hacmi, anketin uygulanabileceği bölgenin belirlenmesinin ardından, istatiksel analiz programına girilerek ana kütle hacmi ve güven aralığına göre hesaplanmıştır. Araştırmanın ana kütlesi Yeşilova ilçesi Merkez Mahallesi ve Koyunlar Çeşme Mahallesi nüfus toplamıdır. 
Tablo 3. Ana Kütlenin Cinsiyetlere Göre Dağılımı

\begin{tabular}{|l|c|c|c|}
\hline \multicolumn{1}{|c|}{ Mahalle Adı } & Toplam Nüfus & Erkek Nüfus & Kadın Nüfus \\
\hline Koyunlar Çeşme Mahallesi & 1.266 & 653 & 613 \\
\hline Merkez Mahallesi & 1.533 & 734 & 799 \\
\hline
\end{tabular}

Kaynak: Yeşilova İlçe Nüfus Müdürlüğü

Yeterli sayıda örnek hesaplamasında $\mathrm{n}=$

$$
\frac{N(p q) Z^{2}}{(N-1) E^{2}+(p q) Z^{2}} \text { formülü kullanılmıştır. }
$$

Örnek hacmi belirlenirken göz önüne alınması gereken bazı önemli unsurlar bulunmaktadır. Bu önemli unsurlar ise, çalışma için alınan kararın önemi, çalışmanın özellikleri, çalışmada kullanılacak olan değişken sayıları, çalışmada kullanılacak olan analizlerin özellikleri ve kaynak sınırlamalardır (Elibol, 2020: 104). Bu çalışmada da en yüksek örneklem seçilmeye çalışılmıştır. Yukarıda belirtilen formülden yararlanılarak kabul edilebilir hata \%7, evren büyüklüğü Yeșilova ilçesi Merkez Mahallesi ve Koyunlar Çeşme Mahallesi 2.799 nüfus toplamı, güven seviyesi \%95 olarak alınmış ve sonuç olarak örneklem hacmi 186 katılımcı olarak belirlenmiştir.

\section{BULGULAR}

Tablo 4. Katılımcılara Ait Demografik Özellikler

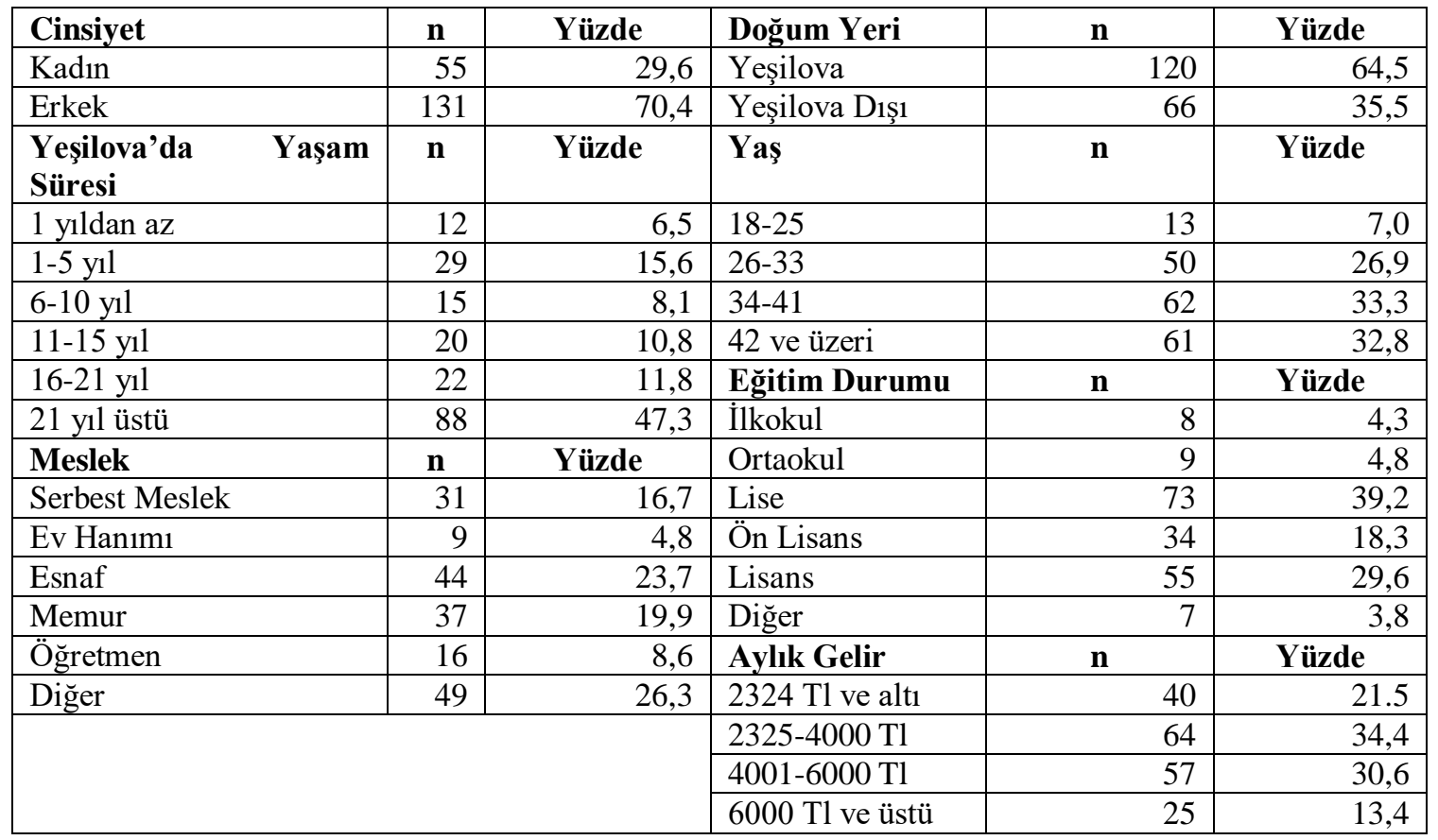

Katılımcılar ile ilgili demografik özellikler Tablo 4'te verilmiştir. Tablo 4 incelendiğinde araştırmaya katılan katılımcıların \%29,6'sının kadın, \%70,4'ünün ise erkek olduğu görülmektedir. Katılımcıların yaş aralığına baktığımız zaman araştırmaya katılan katılımcıların en yüksek \%33,3 oranla 34-41 yaş aralığında olduğu görülmektedir. Daha sonra \%32,8 ile 42 yaş ve üzeri, \%26,9 ile 26-33 yaş ve son olarak \%7 ile 18-25 yaş aralıklarında olan katılımcılar araştırmaya dahil olmuşlardır. Eğitim durumları itibariyle araştırmaya katılan katılımcıların çoğunluğunun \%39,2 oranla lise mezunu olduğu, eğitim durumlarının \% 7'lik oranla en düşük olduğu doktoradır. Ayrıca 
Tablo 4 incelendiğinde araştırmaya katılan 120 katılımcının Yeşilova doğumlu olduğu, 88 katılımcının da 21 yıldan daha fazla Yeşilova ilçesinde yaşadıkları sonucuna ulaşılmıştır. Daha sonra 29 kişinin 1-5 yı1, 22 kişinin 16-21 yıl, 20 kişinin 11-15 yıl, 15 kişinin 6-10 y1l ve 12 kişinin ise 1 yıldan daha az süredir Yeşilova ilçesinde yaşadıkları görülmektedir. Bunlara ek olarak araştırmaya katılan katılımcılar arasında; \%26,3 ile diğer meslek grupları (emekli, akademisyen, özel sektör çalışanı) ilk sırada gelmektedir. Bunu \%23,7'si esnaf, \%19,9'u devlet memuru, \%16,7'si serbest meslek, \%8,6 öğretmen ve \%4,8 ile ev hanımı sırayı takip etmektedir. Son olarak Tablo 4 'te katılımcıların aylık gelirleri incelendiğinde 64 kişinin aylık geliri 2325-4000, 57 kişinin 4001-6000, 40 kişinin $2324 \mathrm{Tl}$ ve altı olduğu ve son olarak 25 kişinin ise $6000 \mathrm{Tl}$ üstü olduğu görülmektedir.

Tablo 5. Doğal ve Kültürel Zenginlikleri Bilme Düzeyi-Yeşilova'da Turizm Denince Akla İlk Gelen ve Ağırlık verilmesi Gereken Turizm Türleri

\begin{tabular}{|c|c|c|}
\hline $\begin{array}{l}\text { Yeşilova'nın Doğal ve Kültürel Turizm Zenginliklerini } \\
\text { Bilme Düzeyi }\end{array}$ & $\mathbf{n}$ & (\%) Yüzde \\
\hline Hiç Bilmiyorum & 5 & 2,7 \\
\hline Çok Az Biliyorum & 7 & 3,8 \\
\hline Biraz Biliyorum & 24 & 12,9 \\
\hline Biliyorum & 95 & 51,1 \\
\hline Çok İyi Biliyorum & 55 & 29,6 \\
\hline Yeşilova'da Turizm Denince Akla İlk Gelen & $\mathbf{n}$ & (\%) Yüzde \\
\hline Salda Gölü & 160 & 86,0 \\
\hline Salda Kayak Merkezi & 15 & 8,1 \\
\hline Beyaz Adalar & 8 & 4,3 \\
\hline Niyazi Baba Türbesi ve Cem Evi & 1 & 0,5 \\
\hline Veli Dede Türbesi & 1 & 0,5 \\
\hline Diğer & 1 & 0,5 \\
\hline Yeşilova'da Ağırlık Verilmesi Gereken Turizm Türleri & $\mathbf{n}$ & (\%) Yüzde \\
\hline Kış Turizmi & 105 & 56,4 \\
\hline Göl turizmi & 151 & 81,2 \\
\hline İnanç Turizmi & 11 & 6,0 \\
\hline Eko Turizm & 39 & 21,1 \\
\hline Kuş Gözlemciliği & 11 & 6,0 \\
\hline Kamp & 1 & 0,54 \\
\hline Karavan & 1 & 0,54 \\
\hline Yaylacılık & 1 & 0,54 \\
\hline Dağcılık & 1 & 0,54 \\
\hline Su Sporlar1 & 1 & 0,54 \\
\hline
\end{tabular}

(Katılımcılar birden fazla seçenek belirtmişlerdir.)

Tablo 5'de araştırmaya katılan katılımcıların Yeşilova'nın doğal ve kültürel turizm zenginliklerini bilme düzeyleri, Yeşilova'da turizm denildiği zaman katılımcıların aklına gelen değerler ile yöre halkının Yeşilova'da ağırlık verilmesi gerektiğini düşündügü turizm türleri verilmiştir. Tablo 5 incelendiği zaman katılımcıların yarıdan fazlası \%51,1'i Yeşilova'daki doğal ve kültürel zenginlikleri bildiğini, \%29,6'sı çok iyi bildiğini, \%12,9'u biraz bildiğini, \%3,8'i çok az bildiğini ve $\% 2,7$ 'si de hiç bilmediğini ifade etmişlerdir. Tablo 5'de elde edilen bu verilere göre katılımcıların $\% 81$ 'e yakını ilçesinin turizm potansiyeli hakkında bilgiye sahip olduğu sonucuna ulaşılmaktadır. Elde edilen bu sonuç doğrultusunda yöre halkının kendi doğal ve kültürel değerlerin farkında olmaları, Yeșilova ilçesi turizminin geliștirilmesi ve sürdürülebilmesi konusunda önem arz etmektedir. Yine Tablo 5 incelendiğinde Yeşilova'da turizm denildiği zaman katılımcıların 
\%86'sının aklına ilk Salda Gölü'nün geldiğini söyleyebiliriz. Daha sonra \%8,1'ine Salda Kayak Merkezinin ve \%4,3'üne Beyaz Adaların ilk akıllarına geldiği yerler olduğu Tablo 5'te görülmektedir. Sonuç olarak, yöre halkı Salda Gölü'nü önemli bir turizm değeri olarak görmektedirler. Ayrıca elde edilen bu veriler ışığında Yeşilova ilçesinin tanıtımında yöre halkının önemli bir turizm değerleri olarak gördükleri bu değerlerin öncelikli olarak kullanılması ayrı bir önem arz etmektedir. Son olarak Tablo 5 tekrar incelendiğinde yöre halkının \% 81,2 'si ilçede öncelikli olarak uygulanmasını istedikleri turizm türünün göl turizmi olduğunu düşünmektedirler. Daha sonra Salda Kayak Merkezi, Yeşilova ilçesi bünyesinde bulunmasından dolayı \%56,4'lük oranla yöre halkının yarısından fazlası kış turizminin uygulanabileceğini de düşünmektedir. Ayrıca yöre halk1 sıra ile \%21,1'lik oranla eko turizmini, \%6'lık oranla inanç turizmini ve kuş gözlemciliğini Yeşilova'nın turizm potansiyeli açısından önem taşıdığını ve bu potansiyellerin kullanılması gerektiğini ifade etmektedirler.

Tablo 6. Faktör Analizi Sonuçları

\begin{tabular}{|c|c|c|c|c|}
\hline $\begin{array}{llll}\text { Kaiser-Meyer-Olkin } & \text { Measure } & \text { of } & \text { Sampling } \\
\text { Adequacy. } & & & \\
\end{array}$ & \multicolumn{2}{|c|}{0,887} & Df. & 231 \\
\hline Bartlett's Test of Sphericity Approx. Chi-Square & \multicolumn{2}{|c|}{2590,271} & Sig. &, 000 \\
\hline Varyansı Açıklama Oranı \% & \multicolumn{2}{|c|}{$\% 14,869$} & $\% 9,220$ & $\% 8,128$ \\
\hline Toplam Varyansı Açıklama Oranı \% & & 3,401 & & \\
\hline \multicolumn{5}{|l|}{ Faktörler } \\
\hline Değişkenler & F1 & F2 & F3 & F4 \\
\hline Yeşilova turizminde önemli alt yapı sorunları vardır. & 0,732 & & & \\
\hline $\begin{array}{l}\text { Yeşilova turizminin gelişmesi açısından ilin temel kuruluş ve } \\
\text { birimleri arasında yeterli ve etkin bir dayanışma ve işbirliği yoktur. }\end{array}$ & 0,690 & & & \\
\hline Yeşilova halk1 turizm konusunda bilinçsizdir. & 0,728 & & & \\
\hline Yeşilovalılar turizme yeterince önem vermemektedir. & 0,666 & & & \\
\hline Yeşilova'nın doğal ve kültürel zenginliklerinin tanıtımı yetersizdir. & 0,492 & & & \\
\hline $\begin{array}{l}\text { Yeşilova turizminin gelişmesi açısından ilin temel kuruluş ve } \\
\text { birimleri arasında etkin bir iletişim ve koordinasyon yoktur. }\end{array}$ & 0,781 & & & \\
\hline Turizm Yeşilova'nın ana gelir kaynağı olabileceğini düşünüyorum. & & 0,730 & & \\
\hline $\begin{array}{l}\text { Yeşilova'nın gelişiminde turizmin lokomotif rol oynayacağını } \\
\text { düşünüyorum. }\end{array}$ & & 0,790 & & \\
\hline $\begin{array}{l}\text { Turizmin Yeşilova ekonomisine } \quad \text { büyük } \\
\text { düşünüyorum. }\end{array}$ & & 0,840 & & \\
\hline $\begin{array}{l}\text { Turizmin Yeşilova'da yeni iş kollarını ve faaliyet alanlarını } \\
\text { arttıracağını düşünüyorum. }\end{array}$ & & 0,847 & & \\
\hline 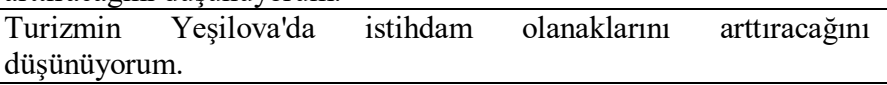 & & 0,863 & & \\
\hline $\begin{array}{l}\text { Yeşilova turizminde başarılı olunabilmesi için turizm faaliyetlerine } \\
\text { yerel halkın ve tüm kesimlerin katılması gerekmektedir. }\end{array}$ & & & 0,775 & \\
\hline $\begin{array}{l}\text { Yeşilova'da turizmin gelişmesi için öncelikle turizm yatırımlarının } \\
\text { arttırılması gerekmektedir. }\end{array}$ & & & 0,734 & \\
\hline $\begin{array}{l}\text { Turizm sadece "Turizm } \\
\text { başarılabilecek bir iş değildir. }\end{array}$ & & & 0,552 & \\
\hline $\begin{array}{l}\text { Turizmin gelişmesi için Yeşilova'nın Burdur, Antalya, Isparta ve } \\
\text { Denizli turizmiyle bütünleşmesi gerekmektedir. }\end{array}$ & & & 0,520 & \\
\hline Yeşilova İlçesi turizm alanında zengin bir potansiyele sahiptir. & & & & 0,505 \\
\hline $\begin{array}{l}\text { Festivallerin, şenliklerin, su ve kayak sporlarının bir ilçenin tanıtımı } \\
\text { ve gelişiminde önemli rol oynamaktadır. }\end{array}$ & & & & 0,504 \\
\hline $\begin{array}{l}\text { Yeşilova İlçesi sahip olduğu göl turizmi potansiyelini yeterince } \\
\text { kullanamamaktadır. }\end{array}$ & & & & 0,825 \\
\hline $\begin{array}{l}\text { Yeşilova İlçesi sahip olduğu kış turizmi potansiyelini yeterince } \\
\text { kullanamamaktadır. }\end{array}$ & & & & 0,595 \\
\hline
\end{tabular}




\begin{tabular}{|l|l|l|l|}
\hline $\begin{array}{l}\text { Yeşilova İlçesi sahip olduğu turizm potansiyelini yeterince } \\
\text { kullanamamaktadır. }\end{array}$ & & & 0,556 \\
\hline $\begin{array}{l}\text { Su ve kayak sporlarının Yeşilova ekonomisine önemli katkılar } \\
\text { sağlayacağına inanıorum. }\end{array}$ & & & 0,623 \\
\hline $\begin{array}{l}\text { Lavanta festivalinin Yeşilova ekonomisine önemli katkılar } \\
\text { sağlayacağına inanıyorum. }\end{array}$ & & & 0,666 \\
\hline
\end{tabular}

Anova Testi yapılmadan önce araştırmaya katılan yerel halkın turizme yönelik tutumlarını oluşturan boyutları inceleyebilmek için araştırma ölçeğinde bulunan 22 önermeye faktör analizi yapılmıştır. Faktör analizinin yapılabilmesi için araştırmaya katılan katılımcı yeterliliğinin sağlanıp sağlanmadığını görmek için Kaiser-Mayer-Olkin (KMO) değerine bakılmış ve bu değer 0,887 olarak bulunmuştur. KMO değeri 0,70'in üzerinde olduğu için iyi bir değer olarak kabul edilmiştir. Daha sonra verilerinden anlamlı faktörler çıkarılabileceğini gösteren küresellik derecesi de (Bartlett's Test of Sphericity) 2590,271 olarak bulunmuş ve elde edilen bu değerin 0,000 düzeyinde istatistiki olarak anlamlı olduğu sonucuna ulaşılmıştır. Faktör analizi sonuçlarına göre, 22 maddelik ölçeğin tek boyutluluk özelliği taşımadığı Tablo 6'dan anlaşılmaktadır. Bu maddelerin 6 tanesi 'Yeşilova Turizminin Sorunları' boyutunu ölçmekte ve toplam varyansın \%31,184'ünü, 5 tanesi 'Turizmin Yeşilova'ya Sağlayacağı Katkılar' boyutunu ölçmekte ve toplam varyansın \%14,869'unu, 4 tanesi 'Turizm Geliştirme Stratejileri' boyutunu ölçmekte ve toplam varyansın \%9,220'sini, son 7 madde ise 'Yeşilova'nın Turizm Potansiyeli Kullanımı ve Etkinlikler' boyutunu ölçmekte ve toplam varyansın \%8,128'ini açıklamaktadır. Faktör analizi sonucunda bu dört faktörün toplam varyansın \%63,401'ini açıkladığı görülmektedir. Son olarak faktör analizi sonucu elde edilen her boyutu ölçmek için oluşturulan önermelerin Cronbach Alpha değerlerine bakılmıştır. $\mathrm{Bu}$ değerler aşağıda maddeler halinde verilmiştir.

- Yeşilova Turizminin Sorunları (Cronbach Alpha; 0,568)

- Turizmin Yeşilova'ya Sağlayacağı Katkılar (Cronbach Alpha; 0,930)

- Turizm Geliştirme Stratejileri (Cronbach Alpha; 0,852)

- Yeşilova'nın Turizm Potansiyeli Kullanımı ve Etkinlikler $(0,656)$

Faktör analizi sonucunda 4'e indirgenen değişkenlerin faktör skorları kukla veriler olarak kabul edilerek Anova testine o şekilde alınmıştır. Aşağıdaki Tablo 7'de Yeşilova ilçe turizminin sorunları faktörü altında toplanan 6 önermeye yerel halkın verdiği cevaplara yer verilmiştir. Tablo 7 incelendiğinde; ilk olarak yerel halk Yeşilova ilçesinin turizmde önemli altyapı sorunları olduğu noktasında konusunda hem fikirlerdir $(\overline{\mathrm{x}}=4,47)$. Bu konuda Tablo 7 meslek bazında dikkate alındığı zaman bu düşünceye en çok öğretmenlerin $(\overline{\mathrm{x}}=4,75)$ katıldıkları görülmektedir. Daha sonra araştırmaya katılan yöre halkı benzer şekilde Yeşilova'nın doğal ve kültürel zenginliklerinin tanıtımının yetersiz olduğu konusunda da ortak bir görüş içindedirler $(\overline{\mathrm{x}}=3,74)$. Özellikle bu konuda en çok desteği verenler sırayla diğer meslek grupları (akademisyen, emekli, özel sektör çalışanı) $(\overline{\mathrm{x}}=4,28)$, öğretmenler $(\overline{\mathrm{x}}=4,12)$ ve ev hanımları $(\overline{\mathrm{x}}=4,11)$ olmuştur. Ayrıca Tablo 7 'de yer alan diğer 4 önerme incelendiğinde; Yeşilova turizminin gelişmesi açısından ilin temel kuruluş ve birimleri arasında yeterli ve etkin bir dayanışma ve işbirliğinin olmadığ konusunda yerel halk aynı görüş birliği içerisindedir $(\overline{\mathrm{x}}=4,10)$. Bu konuda özellikle memurlar $(\overline{\mathrm{x}}=4,10)$ daha yüksek bir kararlılık göstermektedir. Yeşilova turizminin gelişmesi açısından ilin temel kuruluş ve birimleri arasında etkin bir iletişim ve koordinasyonun olmadığ 1 konusunda ise yine yöre halk1 hem fikirdedirler $(\overline{\mathrm{x}}=4,11)$. Yeşilova halkının turizme yeterince önem vermediği de ortak bir kanaat olarak Tablo 7'de görülmektedir $(\overline{\mathrm{x}}=3,37)$. Son olarak yöre halkı Yeşilova halkının turizm konusunda bilinçsiz olduğu noktasında birleşmişlerdir $(\overline{\mathrm{x}}=3,84)$. Bu düşünceye en çok ev hanımları $(\overline{\mathrm{x}}=4,33)$ destek vermektedirler. 
Tablo 7. Yeşilova Turizm Sorunları Faktörü

\begin{tabular}{|c|c|c|c|}
\hline Önermeler & Ĕgitim Durumu & $\mathbf{n}$ & $\overline{\mathbf{x}}$ \\
\hline \multirow{4}{*}{$\begin{array}{l}\text { Yeşilova turizminde önemli alt yapı sorunları vardır. } \\
\text { F: } 1,206 \\
\text { p: } 0,308\end{array}$} & Serbest Meslek & 31 & 4,38 \\
\hline & Ev Hanımı & 9 & 4,55 \\
\hline & Esnaf & 44 & 4,29 \\
\hline & Memur & 37 & 4,37 \\
\hline \multirow{3}{*}{$\begin{array}{l}\text { 1: Kesinlikle Katılmiyorum } \\
\text { 5: Kesinlikle Katıliyorum }\end{array}$} & Öğretmen & 16 & 4,75 \\
\hline & Diğer & 49 & 4,67 \\
\hline & Toplam & 186 & 4,47 \\
\hline \multirow{4}{*}{$\begin{array}{l}\text { Yeşilova'nın doğal ve kültürel zenginliklerinin tanıtımı yetersizdir. } \\
\text { F: } 0,641 \\
\text { p: } 0,669\end{array}$} & Serbest Meslek & 31 & 3,16 \\
\hline & Ev Hanımı & 9 & 4,11 \\
\hline & Esnaf & 44 & 3,36 \\
\hline & Memur & 37 & 3,70 \\
\hline \multirow{3}{*}{$\begin{array}{l}\text { 1: Kesinlikle Katılmiyorum } \\
\text { 5: Kesinlikle Katıliyorum }\end{array}$} & Öğretmen & 16 & 4,12 \\
\hline & Diğger & 49 & 4,28 \\
\hline & Toplam & 186 & 3,74 \\
\hline \multirow{5}{*}{$\begin{array}{l}\text { Yeşilova turizminin gelişmesi açısından ilin temel kuruluş ve } \\
\text { birimleri arasında yeterli ve etkin bir dayanışma ve işbirliği yoktur. } \\
\text { F: } 0,729 \\
\text { p: } 0,602\end{array}$} & Serbest Meslek & 31 & 3,77 \\
\hline & Ev Hanımı & 9 & 4,22 \\
\hline & Esnaf & 44 & 4,09 \\
\hline & Memur & 37 & 4,24 \\
\hline & Öğretmen & 16 & 4,18 \\
\hline \multirow{2}{*}{$\begin{array}{l}\text { 1: Kesinlikle Katılmiyorum } \\
\text { 5: Kesinlikle Katıliyorum }\end{array}$} & Diğer & 49 & 4,18 \\
\hline & Toplam & 186 & 4,10 \\
\hline \multirow{5}{*}{$\begin{array}{l}\text { Yeşilova turizminin gelişmesi açısından ilin temel kuruluş ve } \\
\text { birimleri arasında etkin bir iletişim ve koordinasyon yoktur. } \\
\text { F: } 0,100 \\
\text { p: } 0,992\end{array}$} & Serbest Meslek & 31 & 4,00 \\
\hline & Ev Hanımı & 9 & 4,11 \\
\hline & Esnaf & 44 & 4,11 \\
\hline & Memur & 37 & 4,13 \\
\hline & Öğretmen & 16 & 4,18 \\
\hline \multirow{2}{*}{$\begin{array}{l}\text { 1: Kesinlikle Katılmiyorum } \\
\text { 5: Kesinlikle Katıllyorum }\end{array}$} & Diğer & 49 & 4,14 \\
\hline & Toplam & 186 & 4,11 \\
\hline \multirow{4}{*}{$\begin{array}{l}\text { Yeşilovalılar turizme yeterince önem vermemektedir. } \\
\text { F: } 0,420 \\
\text { p: } 0,834\end{array}$} & Serbest Meslek & 31 & 3,58 \\
\hline & Ev Hanımı & 9 & 3,33 \\
\hline & Esnaf & 44 & 3,22 \\
\hline & Memur & 37 & 3,43 \\
\hline \multirow{3}{*}{$\begin{array}{l}\text { 1: Kesinlikle Katılmiyorum } \\
\text { 5: Kesinlikle Katıliyorum }\end{array}$} & Öğretmen & 16 & 3,06 \\
\hline & Diğer & 49 & 3,44 \\
\hline & Toplam & 186 & 3,37 \\
\hline \multirow{7}{*}{$\begin{array}{l}\text { Yeşilova halk1 turizm konusunda bilinçsizdir. } \\
\text { F: } 0,962 \\
\text { p: } 0,442\end{array}$} & Serbest Meslek & 31 & 3,58 \\
\hline & Ev Hanımı & 9 & 4,33 \\
\hline & Esnaf & 44 & 4,00 \\
\hline & Memur & 37 & 3,91 \\
\hline & Öğretmen & 16 & 4,06 \\
\hline & Diğger & 49 & 3,65 \\
\hline & Toplam & 186 & 3,84 \\
\hline
\end{tabular}

Aşağıdaki Tablo 8'de ise turizmin Yeşilova'ya sağlayacağı katkılar faktörü incelendiğinde Tablo 8'deki bulgulara göre Yeşilova halkı turizmin Yeşilova ekonomisine büyük kakılar sağlayacağını belirtmelerine $(\overline{\mathrm{x}}=4,19)$ rağmen, turizmin Yeşilova'nın ana gelir kaynaği olabileceği konusunda ise temkinli durmaktadırlar $(\overline{\mathrm{x}}=3,74)$. Bu temkinli yaklaşım en fazla serbest meslek $(\overline{\mathrm{x}}=3,45)$ ile esnaflarda görülmektedir $(\overline{\mathrm{x}}=3,45)$. Benzer şekilde yerel halk turizmin Yeşilova'da istihdam olanaklarını $(\overline{\mathrm{x}}=4,17)$ ve iş kollarını arttıracağına inanmakta $(\overline{\mathrm{x}}=4,11)$ fakat Yeşilova'da turizmin lokomotif rol oynaması noktasında ise biraz daha temkinli yaklaşmışlardır $(\overline{\mathrm{x}}=3,96)$. 
Tablo 8. Turizmin Yeşilova’ya Sağlayacağı Katkılar

\begin{tabular}{|c|c|c|c|}
\hline Önermeler & Eğitim Durumu & $\mathbf{n}$ & $\overline{\mathbf{x}}$ \\
\hline $\begin{array}{l}\text { Yeşilova'nın gelişiminde turizmin lokomotif rol oynayacağını } \\
\text { düşünüyorum. } \\
\text { F: } 1,939 \\
\text { p: } 0,090 \\
\text { 1: Kesinlikle Katılmıyorum } \\
\text { 5: Kesinlikle Katılıyorum }\end{array}$ & $\begin{array}{l}\text { Serbest Meslek } \\
\text { Ev Hanımı } \\
\text { Esnaf } \\
\text { Memur } \\
\text { Öğretmen } \\
\text { Diğer } \\
\text { Toplam }\end{array}$ & $\begin{array}{c}31 \\
9 \\
44 \\
37 \\
16 \\
49 \\
186\end{array}$ & $\begin{array}{l}3,51 \\
\mathbf{4 , 4 4} \\
3,75 \\
4,24 \\
4,31 \\
4,04 \\
\mathbf{3 , 9 6}\end{array}$ \\
\hline $\begin{array}{l}\text { Turizmin Yeşilova ekonomisine büyük katkı sağlayacağını } \\
\text { düşünüyorum. } \\
\text { F: } 1,910 \\
\text { p: } 0,095 \\
\text { 1: Kesinlikle Katılmıyorum } \\
\text { 5: Kesinlikle Katılıyorum }\end{array}$ & $\begin{array}{l}\text { Serbest Meslek } \\
\text { Ev Hanımı } \\
\text { Esnaf } \\
\text { Memur } \\
\text { Öğretmen } \\
\text { Diğer } \\
\text { Toplam }\end{array}$ & $\begin{array}{c}31 \\
9 \\
44 \\
37 \\
16 \\
49 \\
186\end{array}$ & $\begin{array}{l}3,74 \\
\mathbf{4 , 5 5} \\
4,00 \\
4,45 \\
4,50 \\
4,30 \\
\mathbf{4 , 1 9}\end{array}$ \\
\hline $\begin{array}{l}\text { Turizm Yeşilova'nın ana gelir kaynağı olabileceğini } \\
\text { düşünyorum. } \\
\text { F: } 1,562 \\
\text { p: } 0,173 \\
\text { 1: Kesinlikle Katılmıyorum } \\
\text { 5: Kesinlikle Katılıyorum }\end{array}$ & $\begin{array}{l}\text { Serbest Meslek } \\
\text { Ev Hanımı } \\
\text { Esnaf } \\
\text { Memur } \\
\text { Öğretmen } \\
\text { Diğer } \\
\text { Toplam }\end{array}$ & $\begin{array}{c}31 \\
9 \\
44 \\
37 \\
16 \\
49 \\
186\end{array}$ & $\begin{array}{r}3,45 \\
4,11 \\
3,45 \\
3,78 \\
\mathbf{4 , 3 1} \\
3,91 \\
\mathbf{3 , 7 4}\end{array}$ \\
\hline $\begin{array}{l}\text { Turizmin Yeşilova'da yeni iş kollarını ve faaliyet alanlarını } \\
\text { arttıracağını düşünüyorum. } \\
\text { F: } 2,608 \\
\text { p: } 0,026 \\
\text { 1: Kesinlikle Katılmıyorum } \\
\text { 5: Kesinlikle Katılıyorum }\end{array}$ & $\begin{array}{l}\text { Serbest Meslek } \\
\text { Ev Hanımı } \\
\text { Esnaf } \\
\text { Memur } \\
\text { Öğretmen } \\
\text { Diğer } \\
\text { Toplam }\end{array}$ & $\begin{array}{c}31 \\
9 \\
44 \\
37 \\
16 \\
49 \\
186\end{array}$ & $\begin{array}{l}3,70 \\
\mathbf{4 , 7 7} \\
3,90 \\
4,37 \\
4,56 \\
4,30 \\
\mathbf{4 , 1 1}\end{array}$ \\
\hline $\begin{array}{l}\text { Turizmin Yeşilova'da istihdam olanaklarını arttıracağını } \\
\text { düşünüyorum. } \\
\text { F: } 2,092 \\
\text { p: } 0,068 \\
\text { 1: Kesinlikle Katılmıyorum } \\
\text { 5: Kesinlikle Katılıyorum }\end{array}$ & $\begin{array}{l}\text { Serbest Meslek } \\
\text { Ev Hanımı } \\
\text { Esnaf } \\
\text { Memur } \\
\text { Öğretmen } \\
\text { Diğer } \\
\text { Toplam }\end{array}$ & $\begin{array}{c}31 \\
9 \\
44 \\
37 \\
16 \\
49 \\
186\end{array}$ & $\begin{array}{l}3,67 \\
\mathbf{4 , 5 5} \\
4,04 \\
4,43 \\
4,50 \\
4,22 \\
\mathbf{4 , 1 7}\end{array}$ \\
\hline
\end{tabular}

Aşağıdaki Tablo 9'da turizm geliştirme stratejileri faktörü altında toplanan önermelere yöre halkının vermiş olduğu cevaplar yer almaktadır. Tablo 9 incelendiğinde yerel halkın Yeşilova'da turizmin gelişmesi için öncelikle turizm yatırımlarının arttırılması gerektiği konusunda görüş birliği içerisinde oldukları görülmektedir $(\overline{\mathrm{x}}=4,32)$. Bu düşünceye en çok ev hanımları $(\overline{\mathrm{x}}=4,88)$ en az ise serbest meslek sahipleri destek vermektedir $(\overline{\mathrm{x}}=3,37)$. Daha sonra sirayla öğretmenler $(\overline{\mathrm{x}}=4,56)$, memurlar $(\overline{\mathrm{x}}=4,40)$, diğer meslek sahipleri $(\overline{\mathrm{x}}=4,38)$ bu düşünceye destek vermektedirler. Ayrıca yöre halkının turizmin gelişmesi için Yeşilova'nın Burdur, Antalya, Isparta ve Denizli turizmiyle bütünleşmesi gerektiği $(\overline{\mathrm{x}}=4,18)$, Yeşilova turizminde başarılı olunabilmesi için turizm 
faaliyetlerine yerel halkın ve tüm kesimlerin katılması gerektiği $(\overline{\mathrm{x}}=4,29)$ ve Yeşilova turizminin sadece Turizm İl Müdürlüğ̈̉'nün çalışmalarıyla başarılabilecek bir iş olmadığı $(\overline{\mathrm{x}}=4,29)$ görüşlerini destekledikleri Tablo 9'daki veriler 1şığında ortaya çıkmaktadır.

Tablo 9. Turizm Geliştirme Stratejileri

\begin{tabular}{|c|c|c|c|}
\hline Önermeler & Eğitim Durumu & $\mathbf{n}$ & $\overline{\mathbf{x}}$ \\
\hline $\begin{array}{l}\text { Yeşilova'da turizmin gelişmesi için öncelikle turizm } \\
\text { yatırımlarının arttırılması gerekmektedir. } \\
\text { F: } 2,149 \\
\text { p: } 0,062 \\
\quad \text { 1: Kesinlikle Katılmıyorum } \\
\text { 5: Kesinlikle Katıliyorum }\end{array}$ & $\begin{array}{l}\text { Serbest Meslek } \\
\text { Ev Hanımı } \\
\text { Esnaf } \\
\text { Memur } \\
\text { Öğretmen } \\
\text { Diğer } \\
\text { Toplam }\end{array}$ & $\begin{array}{c}31 \\
9 \\
44 \\
37 \\
16 \\
49 \\
186\end{array}$ & $\begin{array}{l}3,77 \\
\mathbf{4 , 8 8} \\
4,36 \\
4,40 \\
4,56 \\
4,38 \\
\mathbf{4 , 3 2}\end{array}$ \\
\hline 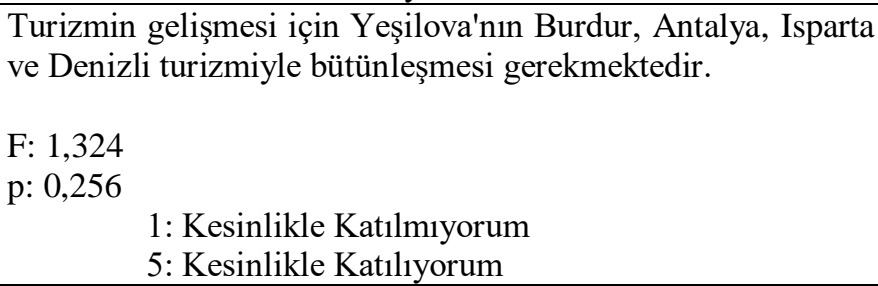 & $\begin{array}{l}\text { Serbest Meslek } \\
\text { Ev Hanımı } \\
\text { Esnaf } \\
\text { Memur } \\
\text { Öğretmen } \\
\text { Diğer } \\
\text { Toplam }\end{array}$ & $\begin{array}{c}31 \\
9 \\
44 \\
37 \\
16 \\
49 \\
186\end{array}$ & $\begin{array}{l}3,96 \\
\mathbf{4 , 8 8} \\
4,06 \\
4,13 \\
4,62 \\
4,18 \\
\mathbf{4 , 1 8}\end{array}$ \\
\hline $\begin{array}{l}\text { Turizm sadece "Turizm İl Müdürlüğünün" çalışmalarıyla } \\
\text { başarılabilecek bir iş değildir. } \\
\text { F: } 4,065 \\
\text { p: } 0,002 \\
\\
\text { 1: Kesinlikle Katılmıorum } \\
\text { 5: Kesinlikle Katılıyorum }\end{array}$ & $\begin{array}{l}\text { Serbest Meslek } \\
\text { Ev Hanımı } \\
\text { Esnaf } \\
\text { Memur } \\
\text { Öğretmen } \\
\text { Diğer } \\
\text { Toplam } \\
\end{array}$ & $\begin{array}{c}31 \\
9 \\
44 \\
37 \\
16 \\
49 \\
186 \\
\end{array}$ & $\begin{array}{l}3,33 \\
4,55 \\
4,15 \\
4,40 \\
\mathbf{4 , 7 5} \\
4,34 \\
\mathbf{4 , 1 8}\end{array}$ \\
\hline $\begin{array}{l}\text { Yeşilova turizminde başarılı olunabilmesi için turizm } \\
\text { faaliyetlerine yerel halkın ve tüm kesimlerin katılmas } \\
\text { gerekmektedir. } \\
\begin{array}{ll}\text { F: } 1,481 & \\
\text { p: } 0,198 & \text { 1: Kesinlikle Katılmıyorum } \\
& \text { 5: Kesinlikle Katılıyorum }\end{array}\end{array}$ & $\begin{array}{l}\text { Serbest Meslek } \\
\text { Ev Hanımı } \\
\text { Esnaf } \\
\text { Memur } \\
\text { Öğretmen } \\
\text { Diğer } \\
\text { Toplam }\end{array}$ & $\begin{array}{c}31 \\
9 \\
44 \\
37 \\
16 \\
49 \\
186\end{array}$ & $\begin{array}{l}3,83 \\
4,55 \\
4,29 \\
4,35 \\
\mathbf{4 , 6 2} \\
4,36 \\
\mathbf{4 , 2 9}\end{array}$ \\
\hline
\end{tabular}

Son olarak aşağıdaki Tablo 10'da Yeşilova'nın turizm potansiyeli kullanımı ve etkinlikler faktörü altında toplanan önermelere yerel halkının vermiş olduğu cevaplar yer almaktadır. Tablo 10'a bakıldığında yöre halkı Yeşilova ilçesinin turizm alanında zengin bir potansiyele sahip olduğunu ( $\overline{\mathrm{x}}$ $=4,08$ ) fakat Yeşilova ilçesinin bu zengin potansiyeli kullanamadiğ 1 konusunda görüş birliğ içerisindedirler $(\overline{\mathrm{x}}=4,24)$. Ayrıca yerel halk Yeşilova'nın hem göl turizmini $(\overline{\mathrm{x}}=4,50)$ hem de kış turizmini yeterince kullanamadığını da ifade etmişlerdir $(\overline{\mathrm{x}}=4,19)$. Son olarak Tablo 10 'da yer alan veriler 1şığında yerel halkın Yeşilova'da, festivaller, şenlikler, su ve kayak sporları yapılırsa ilçenin tanıtımında ve gelişiminde önemli rol oynayacağına $(\overline{\mathrm{x}}=4,16)$, lavanta festivali $(\overline{\mathrm{x}}=4,16)$ ve $\mathrm{Su}$ ve kayak sporları düzenlenirse Yeşilova ekonomisine önemli katkılar sağlayacağına genel olarak inandıkları görülmektedir $(\overline{\mathrm{x}}=4,21)$. 
Tablo 10. Yeşilova'nın Turizm Potansiyeli Kullanımı ve Etkinlikler

\begin{tabular}{|c|c|c|c|}
\hline Önermeler & Eğitim Durumu & $\mathbf{n}$ & $\overline{\mathbf{x}}$ \\
\hline $\begin{array}{l}\text { Yeşilova İlçesi turizm alanında zengin bir potansiyele } \\
\text { sahiptir. } \\
\text { F: } 0,335 \\
\text { p: } 0,891 \\
\\
\quad \text { 1: Kesinlikle Katılmıorum } \\
\text { 5: Kesinlikle Katıliyorum }\end{array}$ & $\begin{array}{l}\text { Serbest Meslek } \\
\text { Ev Hanımı } \\
\text { Esnaf } \\
\text { Memur } \\
\text { Öğretmen } \\
\text { Diğer } \\
\text { Toplam }\end{array}$ & $\begin{array}{c}31 \\
9 \\
44 \\
37 \\
16 \\
49 \\
186\end{array}$ & \begin{tabular}{l|}
4,06 \\
4,22 \\
4,00 \\
$\mathbf{4 , 2 9}$ \\
4,06 \\
4,00 \\
$\mathbf{4 , 0 8}$
\end{tabular} \\
\hline 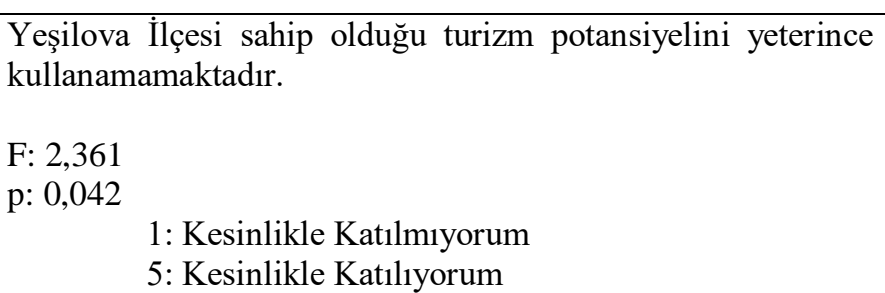 & $\begin{array}{l}\text { Serbest Meslek } \\
\text { Ev Hanımı } \\
\text { Esnaf } \\
\text { Memur } \\
\text { Öğretmen } \\
\text { Diğer } \\
\text { Toplam }\end{array}$ & $\begin{array}{l}31 \\
9 \\
44 \\
37 \\
16 \\
49 \\
186\end{array}$ & $\begin{array}{l}3,74 \\
\mathbf{4 , 5 5} \\
4,04 \\
4,51 \\
4,31 \\
4,46 \\
\mathbf{4 , 2 4}\end{array}$ \\
\hline $\begin{array}{l}\text { Yeşilova İlçesi sahip olduğu göl turizmi potansiyelini } \\
\text { yeterince kullanamamaktadır. } \\
\text { F: } 2,137 \\
\text { p: } 0,063 \\
\\
\quad \text { 1: Kesinlikle Katılmıorum } \\
\text { 5: Kesinlikle Katıllyorum }\end{array}$ & $\begin{array}{l}\text { Serbest Meslek } \\
\text { Ev Hanımı } \\
\text { Esnaf } \\
\text { Memur } \\
\text { Öğretmen } \\
\text { Diğer } \\
\text { Toplam }\end{array}$ & $\begin{array}{l}31 \\
9 \\
44 \\
37 \\
16 \\
49 \\
186\end{array}$ & $\begin{array}{l}3,83 \\
\mathbf{4 , 7 7} \\
4,00 \\
4,43 \\
4,37 \\
4,44 \\
\mathbf{4 , 5 0}\end{array}$ \\
\hline 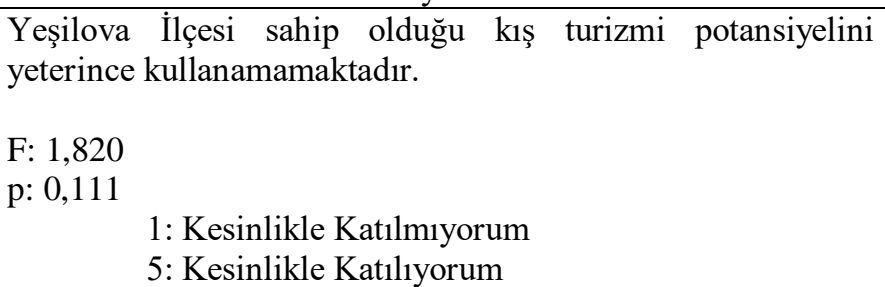 & $\begin{array}{l}\text { Serbest Meslek } \\
\text { Ev Hanımı } \\
\text { Esnaf } \\
\text { Memur } \\
\text { Öğretmen } \\
\text { Diğer } \\
\text { Toplam }\end{array}$ & $\begin{array}{l}31 \\
9 \\
44 \\
37 \\
16 \\
49 \\
186\end{array}$ & $\begin{array}{l}3,80 \\
\mathbf{4 , 8 8} \\
4,09 \\
4,27 \\
4,18 \\
4,34 \\
\mathbf{4 , 1 9}\end{array}$ \\
\hline $\begin{array}{l}\text { Festivallerin, şenliklerin, su ve kayak sporlarının bir ilçenin } \\
\text { tanıtımı ve gelişiminde önemli rol oynamaktadır. } \\
\begin{array}{ll}\text { F: } 1,887 \\
\text { p: } 0,099 \\
\\
\text { 1: Kesinlikle Katılmıyorum } \\
\text { 5: Kesinlikle Katıllyorum }\end{array}\end{array}$ & $\begin{array}{l}\text { Serbest Meslek } \\
\text { Ev Hanımı } \\
\text { Esnaf } \\
\text { Memur } \\
\text { Öğretmen } \\
\text { Diğer } \\
\text { Toplam }\end{array}$ & $\begin{array}{c}31 \\
9 \\
44 \\
37 \\
16 \\
49 \\
186\end{array}$ & $\begin{array}{l}3,67 \\
\mathbf{4 , 6 6} \\
4,13 \\
4,37 \\
4,43 \\
4,16 \\
\mathbf{4 , 1 6}\end{array}$ \\
\hline $\begin{array}{l}\text { Lavanta festivalinin Yeşilova ekonomisine önemli katkılar } \\
\text { sağlayacağına inanıyorum. } \\
\begin{array}{ll}\text { F: } 1,939 \\
\text { p: } 0,090 \\
\\
\text { 1: Kesinlikle Katılmıyorum } \\
\text { 5: Kesinlikle Katıllyorum }\end{array}\end{array}$ & $\begin{array}{l}\text { Serbest Meslek } \\
\text { Ev Hanımı } \\
\text { Esnaf } \\
\text { Memur } \\
\text { Öğretmen } \\
\text { Diğer } \\
\text { Toplam }\end{array}$ & $\begin{array}{c}31 \\
9 \\
44 \\
37 \\
16 \\
49 \\
186\end{array}$ & $\begin{array}{l}3,93 \\
4,66 \\
4,25 \\
4,27 \\
\mathbf{4 , 6 8} \\
3,87 \\
\mathbf{4 , 1 6}\end{array}$ \\
\hline
\end{tabular}




\begin{tabular}{|c|c|c|c|}
\hline $\begin{array}{l}\text { Su ve kayak sporlarının Yeşilova ekonomisine önemli katkılar } \\
\text { sağlayacağına inanıyorum. } \\
\begin{array}{l}\text { F: } 1,840 \\
\text { p: } 0,107 \\
\\
\text { 1: Kesinlikle Katılmıyorum } \\
\text { 5: Kesinlikle Katılıyorum }\end{array}\end{array}$ & $\begin{array}{l}\text { Serbest Meslek } \\
\text { Ev Hanımı } \\
\text { Esnaf } \\
\text { Memur } \\
\text { Öğretmen } \\
\text { Diğer } \\
\text { Toplam }\end{array}$ & $\begin{array}{c}31 \\
9 \\
44 \\
37 \\
16 \\
49 \\
186\end{array}$ & $\begin{array}{l}3,80 \\
\mathbf{4 , 8 8} \\
4,09 \\
\mathbf{4 , 2 1} \\
4,68 \\
4,08 \\
\mathbf{4 , 1 5}\end{array}$ \\
\hline
\end{tabular}

\section{SONUÇ VE ÖNERÍLER}

Yeşilova'nın turizm potansiyeli ve kullanımı ile ilgili literatür taramasında Yeşilova ilçesinin bünyesinde bulunan Salda Gölü'nün turizm potansiyeli, yerli turistlerin Salda Gölü'ne yönelik algıları ve Salda Gölü turizm potansiyelinin Yeşilova ilçesinin sosyo- ekonomik yapısına etkisi üzerinde yapılan araştırmalara rastlanmış fakat Yeşilova yerel halkının ilçe turizmine bakış açıları üzerinde herhangi bir araştırmaya rastlanmamıştır. Bu araştırmada, Yeşilova yerel halkının ilçenin turizm potansiyeline ve ilçede uygulanan turizm faaliyetlerine bakışları ile ilçe turizmine dair gördükleri önemli sorunlar incelenmiştir. Bu kapsam doğrultusunda hem literatür taramasında konuyla ilgili yapılan çalışmaların hem de bu çalışmanın ortak vurgusu; Yeşilova'nın zengin bir turizm potansiyeline sahip olduğu fakat bu potansiyelin tam anlamıyla kullanılamadığıdır. Gerçekten Yeşilova ilçesi bünyesinde bulundurduğu kültürel ve doğal güzellikleri ile zengin bir turizm potansiyeline sahip olduğu söylenebilir. Fakat tüm bu değerlerin ilçe tarafından tam anlamıyla turizme açılıp kullanıldığı söylenemez. Araştırmada elde edilen genel bulgular ışığında, yerel halkın turizm olayına olumsuz bakmadıkları aksine altyapı gibi temel ve öncelikli sorunların ortadan kaldırılarak turizmin Yeşilova'nın ekonomisine önemli katkılar sağlayacağı ve istihdam olanaklarını arttıracağı konusunda hem fikirdirler. Bu sonuç doğrultusunda yerel halkın turizm faaliyetlerine katılımları sağlanarak mevcut turizm potansiyelinin hem sürdürülebilirlik hem de daha da gelişeceği açısından önem arz etmektedir.

Araştırma sonucunda elde edilen diğer bulgular 1şı̆̆ında; katılımcıların çoğunun ilçenin doğal ve kültürel zenginlikleri hakkında yeterince bilgi sahibi oldukları ifade edilebilir. Yöre halkına ilçede turizm denince yöre halkının aklına ilk Salda Gölü olduğu ve bunu Salda Kayak Merkezi takip etmiştir. Bu nedenle de yöre halkı öncelikle ilçede göl turizmine ağırlık verilmesi gerektiğini daha sonrada kış turizminin geliştirilmesi için gerekli adımların atılması gerektiğini ifade etmişlerdir. Ayrıca Yeşilova ilçesinin Burdur, Isparta, Antalya ve Denizli illerine ulaşım mesafesinin kısa olması ilçeye büyük bir avantaj sağlamıştır. Bundan dolayı yöre halkı ilçe turizminin gelişmesi için bu illerin turizmi ile birleştirilmesi ve bu illerdeki tur operatörleri ile diyaloglar geliştirilerek ilçeye turların düzenlenmesi gerektiğini de belirtmişlerdir. Araştırmada çıkan diğer önemli sonuçlar ise;

- Yeşilova ilçesinin turizmde altyapı sorunları bulunduğu ve öncelikli olan altyapı sorunlarının ortadan kaldırılabilmesi için Salda Gölü çevresinde wc-lavabo, duşlukların yapılması, çöpler için gerekli sayıda doğaya uyumlu çöp kutuların konulması, yeme-içme ihtiyacını karşılayabilmek için doğaya uyumlu restoran ve kafelerin, otoparkların ve konaklama ihtiyacının karşılanması için yeterli sayıda konaklama hizmeti veren konaklama ve dinlenme tesislerinin yapılması gerekmektedir.

- İlçe turizminde başarılı olunabilmesi için yerel halk ile birlikte tüm kesimlerin ortak çaba içerisinde olması gerekmektedir.

- Yeşilova'nın doğal ve kültürel zenginliklerinin tanıtımının yeterli bir şekilde yapılması ve ilçe tanıtımında Salda Gölü'nün, Beyaz Adalar'ın ve Salda Kayak Merkezi'nin ön planda tutulmasi gerekmektedir. 
- Yeşilova turizminin gelişmesi ve sürdürülebilmesi için Burdur Valiliği, Burdur İl Turizm Müdürlüğü, Burdur Valiliği Çevre ve Şehircilik İl Müdürlüğü, Yeşilova Kaymakamlığı, Yeşilova Belediyesi, Yeşilova Özel İdare Müdürlüğü, Yeşilova Esnaf Ve Sanatkârlar Kredi Ve Kefalet Kooperatifi ve Yeşilova Ziraat Odası Başkanlığı arasında etkin bir iletişim ve koordinasyonun olmasi gerekmektedir.

- İlçenin tanıtımı, gelişimi ve ilçenin ekonomisine katkı sağlaması için lavanta festivali, su ve kayak sporları gibi turizm faaliyetlerinin yapılmas1 gerekmektedir.

- Yeşilova'da turizmin gelişmesi için öncelikle yerli ve yabancı turistlerin konaklama ihtiyaçlarını karşılayabilecek turistik belgeli konaklama ve dinlenme tesislerinin yapılabilmesi, yeme ve içme ihtiyaçlarını karşılayabilecek restoran ve kafelerin yapılabilmesi, otopark sorunun ortadan kaldırılabilmesi için yeterli sayıda otoparkların yapılabilmesi, gölün temizliğinin korunabilmesi için gerekli yerlere çöp kutularının konulabilmesi ve ziyaretçilerin ihtiyaçlarını karşılayabilecek yeterli sayıda wc-lavabo ve duşlukların yapılabilmesi için turizm yatırımlarının arttırılması gerekmektedir.

- Ayrıca ilçedeki konaklama sorununu çözebilmek için Salda Gölü’nün sit alanı dışındaki yerlere doğal görünümü bozmayacak, doğaya zarar vermeyecek ve doğa ile entegre olacak bungalovların, butik otellerin, aparatların yapılması ve hali hazırda bulunan Salda köyünde ev pansiyonculuğunun teşvik edilmesi gerekmektedir. Bu sayede hem ilçe ekonomisine hem de ilçe turizmine önemli derecede katkıda sağlanmış olunacaktır.

- Özellikle yerel halkın turizm konusunda yeterli düzeyde bilgiye sahip olmadığı sonucuna ulaşılmıştır. Bu nedenle ilçede turizm programlarında eğitim ve öğretim veren İsmail Akın Meslek Yüksekokulu'nda ve Yeşilova Halk Eğitim Merkezi'nde hem yerel halkın hem de esnafların hem turizm konusunda hem hijyen konusunda hem de yerli ile yabancı turistlerle etkin bir iletişim kurabilmeleri konusunda bilinçlendirilebilmesi için gerekli bilgilendirme programlarının yapılması gerektiği sonuçlarına da ulaşılmıştır.

Son olarak araştırmada elde edilen önemli bir diğer sonuç ise ilçede yeterli sayıda turistik belgeli konaklama ve dinlenme tesislerinin bulunmaması ilçeye gelen yerli ve yabancı turistlerin ya günü birlik ziyaretler yapmalarına ya da mola şeklinde konaklama yapmadan gitmelerine neden olmuştur. $\mathrm{Bu}$ nedenle ilçede turistik tesislerin geliştirilmesi, özendirilmesi ve ilçeye gelen yerli ve yabanc1 turistlerin konaklama oranlarının arttırılmasına önem verilmesi gerekmektedir.

\section{KAYNAKÇA}

Akoğlan K., N. \& Türktarhan, G. (2012). Gönüllü Turizmine Kavramsal Bir Bakış. Turizm \& Araştırma Dergisi, 2(1), ss. 1-13.

Arslaner, E. \& Erol, G. (2017). Alternatif Turizmin Bazı Türleri Üzerine Bir Değerlendirme, Journal of Tourism and Gastronomy Studies 5/4, ss. 422-438.

Balc1, N., Demirel, C., Kurt, M. A. (2018). Salda Gölünün Jeomikrobiyolojisi ve Güncel Stromatolit Oluşumunda Mikrobiyal Etkiler, Hacettepe Üniversitesi Yerbilimleri Uygulama ve Araştırma Merkezi Bülteni Yerbilimleri, 39 (1), ss. 19-40.

Burdur İl Kültür ve Turizm Müdürlüğü (2007). Kültür Envanteri Burdur İlçeler. T.C. Burdur Valiliği.

Burdur İl Raporu (1996).

Ceylan, S. (2004). Yazılı Kanyon (Sütçüler, Isparta) Tabiat Parkı'nın Turizm Açısından Önemi Ve Kullanımı, Süleyman Demirel Üniversitesi Burdur Eğitim Fakültesi Dergisi, 5(8), ss. 59-82.

Ceylan, S. \& Demirkaya, H. (2009). Kış Turizmine Bağlı Olarak Gelişen Bir Kırsal Yerleşme: Çobanisa Köyü (Isparta), Doğu Coğrafya Dergisi Sayı 21, ss. 79-94.

December-2020 Vol:5 No:2 International Journal of Turkic World Tourism Studies 
Cook, R., A., Hsu, C., H. \& Marqua, J., J. (Çevirmen, Tuna, M.), (2016), Turizm Konaklama ve Seyahat İşletmeciliği, Beşinci Basım, Nobel Akademik Yayıncılık, Ankara.

Çelik, S. (2018). Alternatif Turizm, Uluslararası Sosyal Araştırmalar Dergisi, 11 (56), ss. 193-204.

Dağtaş S. \& Ünlü, O. (2002), Eşeler Yaylasının Tanıtımı Ve Beklenen Muhtemel İşlevleri, Türkiye Dağları I. Ulusal Sempozyumu, ss. 1-16.

Değirmencioğlu Ö. \& Paşaoğlu S., A. (2008). Anadolu'da Turizm Rehberliği Temel Bilgileri, Gazi Kitap Evi, ÖzBaran Ofset Matbaacılık, Ankara.

Doğan, H. \& Üngüren E. (2012). Yerel Halkın Isparta Turizmine Yönelik Görüşleri Üzerine Bir Araştırma, Süleyman Demirel Üniversitesi İktisadi ve İdari Bilimler Fakültesi Dergisi, 17, (1), ss. 103-122.

Duman, T., Kozak, M. \& Uysal, M. (2007). Turizmde Ürün Çeşitliliği Yoluyla Ürün Değeri Oluşturma: Türkiye' deki Arz Kaynakları Üzerine Bir İnceleme, Anatolia: Turizm Araştırmaları Dergisi, Cilt. 18, Sayl. 2, (206-214).

Elibol A. (2020), Tüketici Satın Alma Kararlarında Tüketici Etnosentrizmi ve Sosyo- Psikolojik Faktörlerin Etkisi, Bucak İşletme Fakültesi Dergisi, 3 (1), ss. 92-130.

Göller Bölgesi Aylık Hakemli Ekonomi ve Kültür Dergisi Ayrıntı, (2017), 4(47), ss. 11-16.

Yeşilova, (2020). http://www.yesilova.gov.tr/ilcemiz-tarihcesi: (Erişim Tarihi: 05.06.2020).

İnanır, A. \& Ongun, U. (2019). Yeşilova Salda'yı Ziyaret Eden Turistlerin Deneyimlerinin İncelenmesi, Türk Turizm Araştırmaları Dergisi, 3(4): 1028-1041.

İpekçioğlu İ. (2014). Burdur Yeşilova Onocak Köyü Veli Dede Türbesi Değerlendirme Rölöve Analiz ve Restinasyon Raporu.

Mellaart, J. AS. (1954), Preliminary Report on a Survey of Pre-Classical Remains in Southern Turkey, AnatSt 4, ss. 175-240.

Kesici, E., Kesici, K. \& Kesici C. (2018). Salda Gölü Korunan Alanının Sürdürülebilirliği, Doğanın Sesi, 1 (1), ss. 3-11.

Lopez-Guzman, T. \& Sanchez-Canizares, S. (2012). Gastronomy, Tourism and Destination Differentiation: A Case Study in Spain. Review of Economics \& Finance, 2, 63-72.

Orhan, T. \& Karahan, F. (2010). Uzundere İlçesi ve Yakın Çevresinin Ekoturizm Potansiyelinin Değerlendirilmesi, Artvin Çoruh Üniversitesi Orman Fakültesi Dergisi, 11 (1), ss. 27-42.

Ongun, U., Gövdere, B. \& Çiçek, U. (2016), Yeşilova'nın Kırsal Turizm Potansiyelinin Swot Analizi İle Değerlendirilmesi, Süleyman Demirel Üniversitesi, Vizyoner Dergisi, 7 (16), ss. 75-88.

Özsait 1984 M. Özsait, "Burdur Çevresinde Prehistorik Araştırmaları”, Araştırma Sonuçları Toplantısı 1, ss. $7-12$.

Özsaid, M. (2005), Arkeolojik Verilerin Işı̆ğı Altında Burdur, I. Burdur Sempozyumu: Bildiriler, Mehmet Akif Ersoy Üniversitesi, ss. 696-715.

Kalafat Ş. (1999), Diyanet İşleri Başkanlığı Arşivine Göre Horasan Eri Olarak Bilinen Anadolu Yatırları -I, Ankara Üniversitesi İlahiyat Fakültesi Dergisi, 40 (1), ss. 511-535

Korkmaz E. (2020), Salda Raporu. (http://www.tmmob.org.tr/sites/default/files/tmmobsaldagoluraporu_1.pdf, Erişim Tarihi: 10.11.2020).

Russell, M. J., Ingham, J. K., Zedef, V., Maktav D., Sunar, F., Hall, A. J., Fallıck, A. E., (1999). Search For Signs Of Ancient Life On Mars: Expectations From Hydromagnesite Microbialites, Salda Lake, Turkey, Journal Of The Geological Society, London, Vol. 156, pp. 869-889. 
Taş, M., Düz, İ. \& Ünlü, E. (2016). Ortaöğretim Öğrencilerinin “Alternatif Turizm” Kavramına İlişkin Algılarının Metaforlar Yardımıyla Analizi, Eğitim ve Öğretim Araştırmaları Dergisi, Özel Sayı, C. 5, ss. 352-360.

Temurçin, K., Atayeter, Y. \& Tozkoparan, U. (2019). Salda Gölü ve Çevresinin Turizm Potansiyeli ve Yeşilova İlçesi’nin Sosyo-Ekonomik Yapısına Etkisi, Süleyman Demirel Üniversitesi Fen-Edebiyat Fakültesi Sosyal Bilimler Dergisi, 2 (47), ss. 40-63.

Temurçin, K. \& Tozkoparan U. (2020). Yerli Turistlerin Salda Gölü’ne Yönelik Görüşlerinin Değerlendirilmesi, Turizm Akademi Dergisi, 7 (1), ss. 97-115.

Tozkoparan, U. (2020). Salda Gölü, Doğal Özelliklerini Koruyarak Geleceğe Taşımalıyı, Yenises, Sayı, 298, Ekim, ss. 28-30.

Usta, Ö. (2016). Turizm Genel ve Yapısal Yaklaşım, 5. Baskı, Detay Yayıncılık, Ankara.

Yeşilova İlçe Nüfus Müdürlüğü (2020).

Yılmaz, A. \& Şahin, K. (2009). Samsun Şehri ve Yakın Çevresinde Turizm Ve Turist Algılaması, Uluslararası Sosyal Araştırmalar Dergisi, 2 (7), ss. 345-358. 